\title{
Pengaruh Pesan Gambar Bahaya Merokok Terhadap Perubahan Perilaku Perokok
}

\section{Effect of Picture Message Warning Against Smoking Behaviour Change Smoker}

\author{
I Adiayatama, U Suryatna, AA Kusumadinata ${ }^{1 a}$ \\ Ps. Ilmu Komunikasi, Fakultas Ilmu Sosial dan Ilmu Politik, Universitas Djuanda Bogor, \\ Jl Tol Ciawi No.1 Kotak Pos 35 Bogor 16720 \\ a Korespondensi: AA Kusumadinata, Email: alialamsyahkusumadinata@gmail.com
}

(Ditelaah: 20-01-2016; Disetujui: 24-02-2016)

\begin{abstract}
This study focuses on the relationship Influence Picture Message Warning Smokers Smoking by Behavior Change. The aim of the study was (1) To determine the presentation format and content of a picture message warning the dangers of smoking on cigarette packs, (2) to determine the effects of cognitive, affective, and behavioral warning and picture messages contained the dangers of smoking on cigarette packs, and (3) to determine the influence of a picture message warning the dangers of smoking on cigarette packs on the behavior of smokers. This research was carried out against members of Family Theater Campus Bogor, whose population amounts to 50 people, and the amount of study sample as many as 44 people. This study used a descriptivecorrelational. Data were collected using a questionnaire. Research results show that (1) graphics format danger warning pictures on cigarette packs is good, in a position that is easily seen, its size proportionally, writing explaining the displayed image and use the appropriate color. Picture message content dangers of smoking rational and morally good for health and the environment. (2) the cognitive effects of warning the dangers of smoking have not been able to raise awareness of the dangers of smoking, although it is understood that smoking is harmful to health. Affective effect warning the dangers of smoking have not been able to foster fear and feeling threatened. Warning of the dangers of smoking behavioral effects have not been able to cause people to avoid smoking, quit smoking and avoid association with those of smokers. (3) Message text and images hazard warnings on cigarette packs significantly influenced changes in the behavior of smokers by $25 \%$. Due to the influence of picture messages warning of the dangers of smoking on cigarette packs are relatively small contribution to change the behavior of smokers, so to change the behavior of smokers, calls picture messages dangers of smoking needs to be followed by other policies that limit the space for smokers, there by reducing the opportunity for conducting smoke.
\end{abstract}

Keywords : Picture Messages, Behaviour.

\section{Abstrak}

Penelitian ini memusatkan perhatian pada Hubungan Pengaruh Pesan Gambar Peringatan Bahaya Merokok degan Perubahan Perilaku Perokok. Tujuan dari penelitian adalah (1) untuk mengetahui penyajian format dan isi pesan gambar peringatan bahaya rokok pada bungkus rokok, (2) untuk mengetahui efek kognitif, afektif, dan behavioral pesan gambar peringatan bahaya merokok yang terdapat pada bungkus rokok, dan (3) untuk mengetahui besarnya pengaruh pesan gambar peringatan bahaya rokok pada bungkus rokok terhadap perilaku perokok. Penelitian ini dilakukan terhadap anggota Keluarga Teater Kampus Bogor (KTKB), yang populasinya berjumlah 50 orang, dan jumlah sample penelitian sebanyak 44 orang. Penelitian ini menggunakan metode deskriptif-korelasional. Hasil Penelitian menunjukkan bahwa (1) format grafis gambar peringatan bahaya merokok pada bungkus rokok sudah baik, pada posisi yang mudah dilihat, ukurannya proporsional, tulisannya menjelaskan gambar yang ditampilkan serta penggunaan warna yang sesuai. Isi pesan gambar bahaya merokok rasional dan secara moral tidak baik, bagi kesehatan maupun lingkungan. (2) efek kognitif peringatan bahaya merokok berlum mampu menumbuhkan kesadaran akan bahaya merokok, walaupun dipahami bahwa merokok berbahay bagi kesehatan. Efek afektif peringatan bahaya merokok berlum mampu menumbuhkan rasa takut dan perasaan terancam. Efek behavioral peringatan bahaya merokok belum mampu menyebabkan orang 
menghindari rokok, berhenti merokok dan menghindari pergaulan dengan orang-orang perokok. (3) Pesan tulian dan gambar peringatan bahaya merokok pada bungkus rokok berpengaruh nyata terhadap perubahan perilaku perokok sebesar 25\%. Karena pengaruh pesan gambar peringatan bahaya merokok pada bungkus rokok relative kecil kontribusinya terhadap perubahan perilaku perokok, maka untuk mengubah perilaku merokok, himbauan pesan bahaya merokok perlu diikuti dengan kebijakan lain yang membatasi ruang gerak perokok, sehingga dapat mengurangi kesempatan untuk melakukan kegiatan merokok.

Kata Kunci : Pesan Gambar, Perilaku.

I Adiayatama, U Suryatna, AA Kusumadinata. 2016. Pengaruh Pesan Gambar Peringatan Bahaya Merokok Terhadap Perubahan Prilaku Perokok. Jurnal Komunikatio 2(1): Halaman 67-95. 


\section{PENDAHULUAN}

Berdasarkan data United States of Departement of Agriculture (USDA) pada tahun 2002, Indonesia menduduki urutan kelima sebagai negara dengan konsumsi tembakau tertinggi dunia setelah Cina, Amerika, Rusia, dan Jepang. Keadaan ini terjadi akibat peningkatan tajam konsumsi tembakau dalam 30 tahun yaitu dari 30 milyar batang rokok pertahun di tahun 1970 ke 217 milyar batang rokok di tahun 2000. Dari hasil survei Departemen Kesehatan RI (Depkes RI) pada tahun 2003, hampir satu dari tiga orang dewasa merokok dan lebih banyak pria pedesaan yang merokok (67\%) dibandingkan dengan pria dari perkotaan $(58,3 \%)$. Selain itu, sebagian besar perokok $(68,8 \%)$ mulai merokok sebelum umur 19 tahun. Berdasarkan data tahun 2004, Indonesia merupakan negara ke- 6 penghasil tembakau dunia setelah China, Brazil, India, USA dan Turkey. Tembakau yang dihasilkan sebesar 160.000 metrik ton dengan luas lahan lebih dari 145.000 hektar dengan pekerja yang tercatat 2.539.000 orang. Penggunaan tembakau di Indonesia menyebabkan 70\% kematian karena penyakit paru kronik dan emfisema. Data Susenas 2001 memperkirakan penggunaan tembakau menyebabkan lebih dari 5 juta kasus kesakitan dan 400.000 kematian, (Pusat Komunikasi Publik, Sekretariat Jenderal Departemen Kesehatan RI, 2007).

Menyikapi dampak buruk merokok terhadap kesehatan pemerintah telah mengeluarkan peraturan larangan merokok di tempat-tempat umum dan mewajibkan kepada setiap perusahaan rokok mencantumkan peraturan bahaya merokok dalam setiap bungkus rokok. Saat ini masih banyak pro dan kontra dikalangan masyarakat dalam menanggapi peraturan larangan merokok. Sebagian pihak merasa akan lebih terjaga dari bahaya rokok, namun peraturan ini dinilai sangat merugikan para pihak petani tembakau, karena tembakau adalah bahan utama pembuatan rokok, dan banyak para karyawan pabrik penghasil rokok yang hidupnya tergantung pada produksi rokok. Selain itu menurut [mantan ]Menteri Perindustrian Fahmi idris dalam liputan6.com), penerimaan Negara atau penghasilan Negara dari cukai dan pajak rokok yang merupakan single commodity, mencapai Rp. 52 Triliun, sehingga kalau prilaku merokok dilarang tuntas, hal tersebut akan banyak merugikan Negara.

Pemerintah sudah berulang kali mengubah kalimat himbauan bahaya merokok pada setiap bungkus rokok atau di setiap iklan yang awalnya peringatan bertuliskan "Merokok dapat menyebabkan serangan jantung, impotensi, gangguan kesehatan dan janin", kalimat tersebut sepertinya juga tidak berpengaruh terhadap perokok Pemerintah mengganti kalimat tersebut dengan tulisan "merokok membunuhmu" kalimat tersebut juga tidak cukup efektif. Pemerintah kemudian mengeluarkan peraturan yang baru mengenai peringatan bahaya merokok, selain tulisan peringatan bahaya merokok juga ditampilkan gambar dan peringatan beberapa jenis penyakit yang diakibatkan oleh merokok dalam bentuk gambar/ilustrasi pada kemasan bungkus rokok yang diharapkan dapat menimbulkan rasa takut (fear arousing), agar menimbulkan kesan bahwa bahaya merokok itu memang nyata adanya dapat membunuh perokok serta berbahaya bagi lingkungan sekitar.

Sebelumnya peringatan bahaya merokok yang terdapat pada kemasan bungkus rokok, sepertinya tidak berdampak signifikan untuk mengurangi jumlah perokok, diduga karena peringatan bahaya merokok dalam bentuk tulisan saja tidak menimbulkan rasa takut bagi perokok dan berhenti merokok, karena mungkin sebagian besar perokok tidak menghiraukan tulisan yang terdapat pada kemasan bungkus rokok. Dengan diterbitkannya aturan, bahwa peringatan bahaya merokok pada kemasan bungkus rokok harus dilengkapi dengan gambar/ilustrasi bahaya penyakit yang ditimbulkan akibat merokok, diharapkan dapat menyadarkan para pecandu rokok akan bahaya merokok yang dapat berakibat terkena penyakit yang dapat menyebabkan kematian.

Direktorat Jendela Pengendalian Penyakit dan Penyehatan Lingkungan Kementerian Kesehatan, Prof. Tjandra Yoga Aditama mengatakan semua kemasan rokok di Indonesia wajib diisi lima gambar peringatan bahaya merokok mulai 24 Juni 2014. "Semua perusahaan rokok di Indonesia sudah sepakat untuk memasang lima gambar bahaya merokok seiring dengan sosialisasi Peraturan Pemerintah Nomor 109 Tahun 2012 tentang Pengamanan 
Bahan Yang Mengandung Zat Adiktif Produk Tembakau Bagi Kesehatan yang sudah disosialisasikan selama 1,5 tahun terakhir," katanya di sela-sela Kampanye PeringatanRokok Bergambar, di Denpasar (www.antaranews.com).

Terhadap peraturan tersebut semua produsen rokok telah sepakat untuk memasang lima buah gambar akibat dari merokok yang akan menjadi gambar iklan dan kemasan dari setiap produk yang mereka pasarkan. Namun, tidak semua gambar akan langsung dipasang dalam satu kemasan, melainkan akan dibagibagi sehingga beraneka ragam kemasan rokok dengan gambar akibat dari bahaya merokok. peraturan ini dibuat agar masyarakat lebih mengetahui lagi bahaya dari merokok, sehingga lambat laun akan membuat Indonesia bebas dari perokok. Pemerintah menyadari bahwa usaha untuk mewujudkan bebas rokok sangatlah susah, oleh karena itu terobosan baru ini dibuat untuk memberikan efek berfikir kepada para perokok yang nantinya akan menjadi seperti gambar yang ada dalam kemasan rokok tersebut. Apabila ada pabrik rokok yang tidak mengikuti peraturan ini pemerintah akan dikenakan sanksi lima tahun penjara atau membayar denda Rp 500 juta bagi pihak yang secara sengaja tidak mencantumkan peringatan tersebut. Sedangkan untuk produk rokok yang sudah beredar, perusahaan rokok diminta untuk menarik rokok yang sudah beredar tersebut dalam jangka waktu waktu 2-3 bulan setelah diterbitkannya peraturan tersebut, jika tidak ditarik, perusahaan rokok yang bersangkutan akan diberikan sanksi.

Di Indonesia, masalah rokok telah menjadi perbincangan banyak orang. Hal utama yang dibahas sudah tentu mengenai masalah yang disebabkan oleh rokok, baik bagi kesehatan ataupun kualitas hidup pecandunya. Perkembangan konsumsi rokok di Indonesia sudah bukan lagi pada kalangan orang dewasa saja, tetapi sudah merambah kepada anak-anak remaja dan bahkan anak kecil di Indonesia. Oleh karena itu pemerintah berusaha secara terus-menerus untuk mengurangi bahkan menghentikan kebiasaan merokok pada pecandu rokok dengan berbagai kegiatan sosialisasi dan peringatan pada masyarakat tentang bahaya meokok.

Peringatan gambar yang terdapat pada bungkus rokok dapat dikategorikan ke dalam bentuk Iklan Layanan Masyarakat (ILM) yang bersifat desain Grafis, karena dalam himbauan tersebut berisi tentang informasi berbentuk gambar bahaya merokok untuk kesehatan dan himbauan tersebut dicetak pada bungkus rokok melalui desain grafis berbentuk gambar. Pada dasarnya himbauan tersebut adalah langkah yang diposisikan untuk membangun kesadaran diri, sedangkan sifat pesan hanya berupa peringatan. Maka, tidak ada risiko hukuman bagi mereka yang tidak memenuhinya.

Peringatan gambar yang disampaikan dapat menimbulkan efek yang berbeda-beda bagi komunikannya, oleh karena itu agar ilsutrasi/gambar tersebut diharapkan dapat menimbulkan efek yang sesuai dengan keinginan komunikator, maka menurut Kotler (dalam Margono, 2008:34) himbauan tersebut harus memilki format pesan yang baik untuk sebuah ILM dan daya tarik pesan yang meliputi daya tarik emosional, daya tarik rasional dan daya tarik moral. Sedangkan menurut Rakhmat (2005:219), efek pesan media massa meliputi aspek : Kognitif, afektif, serta behavioral. Efek kognitif terjadi apa bila ada perubahan pada sesuatu yang diketahui atau dipahami oleh khalayak. Efek afektif timbul bila ada perubahan yang dirasakan oleh khalayak, sementara efek behavioural merujuk pada prilaku yang nyata, yang dapat diamati. Dengan demikian variable yang dapat diukur dalam penelitian ini terkait dengan efek behavioural, yaitu untuk mengetahui apakah perokok mengetahui atau bahkan memahami gambar peringatan dan menimbulkan sikap hingga ke perilaku tidak lagi merokok dan atau mengurangi jumlah rokok yang dihisap setiap harinya.

Objek penelitian ini adalah anggota Keluarga Teater Kampus Bogor (KTKB), komunitas ini dijadikan obyek penelitian karena sebagian besar anggota dari komunitas ini adalah mahasiswa yang bersusia antara 1925 tahun dan kebanyakan adalah perokok. Anggota kelompok ini umumnyas menghisap rokok jenis filter yaitu jenis Rokok yang mengandung TAR dan Nikotin yang cukup tinggi. Jenis rokok filter berisi 12 batang rokok dengan ukuran bungkus rokok yang yang ratarata sebesar $9 \mathrm{~cm} \mathrm{x} \mathrm{6,5} \mathrm{cm,} \mathrm{sehingga} \mathrm{ukuran}$ pesan gambar pada bungkus rokok tersebut mudah dilihat. Penempatan pesan gambar pada kemaan bungkus rokok berbentuk pesan tunggal yang luas permukaanya kira-kira 50\% dari permukaan bagian depan dan belakang 
bungkus rokok. Ditempatkan pada bagian atas bungkus rokok tidak tertutup atau terhalang apapun sehingga dapat dengan mudah dilihat. Seberapa besar efek pesan gambar peringatan bahaya merokok pada keamasan bungkus rokok terhadap perubahan perilaku perokok sebagai fenomena komunikasi yang menarik untuk diteliti. Penelitian ini mengambil judul "Pengaruh Pesan Gambar Peringatan Bahaya Merokok Terhadap Perubahan Prilaku Perokok".

\section{Rumusan Masalah}

Berdasarkan latar belakang sebagaimana telah dikemukakan di atas permasalahan penelitian dirumuskan sebagai berikut :

1. Bagaimanakah format dan isi pesan gambar peringatan bahaya merokok pada bungkus rokok?

2. Bagaimanakah efek kognitif, afektif, dan behavioral pesan gambar peringatan

\section{METODE PENELITIAN}

Penelitian ini menggunakan pendekatan Kuantitatif. Sampel yang digunakan sebanayak 44 Orang. Data yang diambil adalah data primer yang langsung diambil dengan kuesioner dan wawancara mendalam kepada responden. Penelitian ini dilakukan pada Bulan Novemver 2014. Lokasi penelitian ini dilakukan di sekretariat KTKB (Keluarga Teater Kampus Bogor ) yang terletak didalam gedung kamuning gading Jl. Ir. H. Juanda No.10 Bogor-16121. Penelitian ini dilakukan pada anggota KTKB perokok yang juga tercatat sebagai mahasiswa yang ada di kota Bogor seperti mahasiswa

\section{HASIL DAN PEMBAHASAN}

\section{Keluarga Teater Kampus Bogor}

Keluarga Teater Kampus Bogor (KTKB) merupakan perkumpulan mahasiswa dari berbagai perguruan tinggi yang ada di Bogor yang memiliki minat dalam bidang kesenian teater. KTKB merupakan sebuah ruang pembelajaran yang tak terbatas bagi individuindividu yang mencoba mengembangkan bahaya merokok yang terdapat pada bungkus rokok?

3. Seberapa besar pengaruh pesan gambar peringatan bahaya rokok pada bungkus rokok terhadap perilaku perokok?

\section{Tujuan Penelitian}

Berdasarkan rumusan masalah yang telah dikemukaan di atas, maka tujuan penelitian adalah sebagai berikut:

1. Untuk mengetahui penyajian format dan isi pesan gambar peringatan bahaya rokok pada bungkus rokok.

2. Untuk mengetahui efek kognitif, afektif, dan behavioral pesan gambar peringatan bahaya merokok yang terdapat pada bungkus rokok.

3. Untuk mengetahui besarnya pengaruh pesan gambar peringatan bahaya rokok pada bungkus rokok terhadap perilaku perokok.

Universitas Pakuan, UIKA, IPB, Kimia Analisis,UNIDA dan BSI, dengan pertimbangan pemilihan lokasi al. yaitu (1) Keluarga Teater Kampus Bogor sebagian besar adalah perokok. (2) Lokasi penelitian dekat dengan peneliti, Sehingga memudahkan peneliti untuk memperoleh data dan biaya relatif lebih kecil. (3) Secara metedologis keberadaan mahasiswa tersebut ada didalam sekretariat yang berdekataan dengan perkotaan dan tempat -tempat umum dari wilayah tersebut rentan terhadap pengaruh bahaya merokok dan perbedaan tersebut akan menimbulkan efek terhadap bahaya merokok . Sehingga mereka bisa sebagai sampel penelitian tentang bahaya merokok dari suatu populasi.

potensi diri dan pemikirannya. Sebuah ruang apresiasi kesenian yang tentunya perlu ditopang oleh berbagai hal untuk perkembangannya. Komunitas ini didirikan pada tanggal 6 Maret 2010 yaitu oleh para pelaku seni unit kegiatan mahasiswa yang ada di kampus Bogor. Keluarga Teater Kampus Bogor bersekretariat di dalam Gedung Kesian Kamuning Gading JL.Ir.H.Juanda No.10 Kota Bogor-16121. Anggota KTKB adalah mahasiswa yang mengikuti unit kegiatan 
mahasiswa teater atau yang berkaitan seni yang lokasi kampusnya di Bogor.

Peringatan bahaya merokok yang tercantum dalam setiap kemasan bungkus rokok, dan terdapat pada setiap iklan rokok pada medioa cetak dan elektronik serta di tempat-tempat umum, dapat dikategorikan sebagai Iklan Layanan Masyarakat (ILM), karena pesan yang disampaikan bukan untuk tujuan komersial, tetapi berupa himbauan agar masyarakat mengurangi atau bahkan menghindari rokok. Menurut Burhan Bungin (dalam Margono, 2008:31) Iklan Layanan Masyarakat (ILM) ini pesannya berasal dari golongan atau instansi tertentu (Pemerintah, LSM, masyrakat, kelompok) yang memberikan informasi tentang sesuatu yang harus diketahui dan dituruti oleh masyarakat. Iklan ini lebih dimaksudkan untuk memberikan informasi tentang sesuatu yang penting bagi masyarakat luas.

Untuk menyebarkan informasi ILM ini dapat menggunakan media massa yang bersifat audio, visual, audio-visual maupun media luar ruang (bellow the line) dengan media massa yang telah banyak menghiasi sistem komunikasi massa yang telah dikenal banyak dikalangan masyarakat, seperti:

1. Media cetak, seperti surat kabar harian, majalah, tabloit, dan pamflet yang banyak berisi informasi.

2. broadcast, seperti media televisi dan radio.

3. Media cyber, seperti internet.

4. Media luar ruang, seperti poster, baliho, pameran dan kartu-kartu transit.

5. Informasi grafis, berupa penyampai pesan yang berisi informasi dalam berbagai macam bentuk grafis atau visual.

Menurut Slamet Hariyadi (2011:7) Informasi grafis adalah suatu komunikasi yang bersifat visual yang menggunakan gambar untuk menyampaikan informasi atau pesan seefektif mungkin. Dalam informasi grafis, teks juga dianggap gambar karena merupakan hasil abstraksi simbol-simbol yang bisa dibunyikan. Seni dalam informasi grafis ini mencakup kemampuan kognitif dan keterampilan visual, sehingga dalam informasi grafis ini harus memperhatikan ilustrasi, warna, pengolahan gambar dan tata letak, agar komunikan tertarik untuk melihat informasi grafis tersebut.

Pesan tulisan dan gambar peringatan bahaya merokok yang terdapat dalam bungkus rokok termasuk kedalam ILM, karena isi himbauan pesan tersebut memberikan informasi tentang bahaya merokok. Isi dari himbauan tersebut adalah untuk menginformasikan kepada komunikan bahwa merokok dapat berbahaya bagi kesehatan atau dapat menimbulkan penyakit. Di Indonesia ILM ini dikemas dalam bentuk informasi desain grafis, yaitu penyampian informasi ini disampaikan dengan menggunakan pesan tulisan dan gambar yang dicetak dalam semua bungkus rokok. Dalam penelitian ini, ILM yang terdapat dalam bungkus rokok menggunakan huruf atau font Calibri dengan ukuran 12 dengan spasi satu atau single, tulisan tersebut menggunakan warna hitam dengan dasar berwana hitam. Selain itu, himbauan tersebut diletakkan di bawah gambar peringatan, untuk gambara peringatan sendiri mempunyai ukuran $5 \times 3,5 \mathrm{~cm}$ dengan tampilan gambar mirip dengan aslinya dengan kombinasi perpaduan warna yang sangat menarik, gambar peringatan terletak pada bagian atas bungkus rokok yang berada pada tutup bungkus rokok.

Warna gambar peringatan dalam bungkus rokok terlihat begitu menarik dengan perpaduan warna yang seperti gambar aslinya atau gambar yang disebabkan oleh rokok. Menurut david Dabner (dalam Sitepu 2005:23) Warna memberikan kesan pesan yang sangat mendalam, kombinasi antar warna memberi kesan visual yang bervariasi. Warna merupakan alat untuk menarik perhatian pembaca, warna yang dipilih menimbulkan efek yang luar biasa pada pesan dan cara orang meresponnya (Feedback).

Tata letak himbauan ini berada di atas bungkus rokok,dengan gambar terletak pada tutup depan dan terletak pada blakang bungkus rokok sehingga berada dalam posisi yang mudah dilihat oleh perokok, terutama saat mereka akan mengambil rokok yang posisi pembuka bungkus rokok tersebut berada di depan.

Menurut Kotler (dalam Margono, 2008:34) dalam merancang pesan Iklan khususnya ILM diperlukan empat pemecahan masalah, salah satunya adalah isi pesan. Pengiklan harus lebih memperhatikan apa yang dikatakan (What to say) pada khalayak sasaran agar menghasilkan tanggapan (respon) yang diharapkan. Dalam menentukan isi pesan yang terbaik, manajemen harus mencari daya tarik yang unik. Ada tiga daya tarik isi pesan 
khususnya untuk ILM yaitu: daya tarik rasional, daya tarik emosional dan daya tarik moral. Isi pesan dalam himbauan bungkus rokok yang menjadi subjek dalam penelitian ini adalah: pesan tulisan dan gambar peringatan bahaya merokok.

Daya tarik rasional digunakan untuk membangkitkan kepentingan diri audiens, yang menunjukan bahwa produk tersebut akan menghasilkan manfaat yang dikatakan. Menurut Terry and Horn (dalam Dinata, 2008:43) terdapat kurang lebih 3.000 bahan kimia dan sampai saat ini belum diketahui secara persis berapa banyak diantaranya yang berbahaya bagi kesehatan. Bahkan, dari 3.000 jenis bahan kimia tersebut baru 700 jenis yang dikenal. Beberapa zat tersebut adalah Karbo monoksida (Co) yang dapat menyebabkan seseorang dapat terkena serangan jantung, selain itu Co juga menimbulkan gangguan sirkulasi darah di kaki sehingga bagi wanita perokok akan berisiko untuk meminum pil $\mathrm{Kb}$ yang akan menyebabkan gangguan kehamilan dan janin. Selain Co zat berbahaya lain adalah Nikotin yang dapat menyebabkan kecanduan dan mempengaruhi sisitem syaraf sehingga dapat menambah risiko penyakit jantung. Selain itu, Nikotin dan Co dapat membuat pembuluh darah di plasenta mengecil sehingga dapat menimbulkan gangguan janin pada wanita hamil. Zat lain yang terdapat dalam satu batang rokok dan menimbulkan penyakit adalah TAR yang dapat menyumbat dan mengiritasi paru-paru sehingga dapat menyebabkan penyakit Bronchitis kronis, Emphysema dan dalam beberapa kasus menyebabkab kanker paru-paru. Oleh sebab itu, isi himbauan pesan yang terdapat dalam bungkus rokok terlihat memiliki daya tarik rasional karena sesuai dnegan fakta bahwa merokok dapat menyebabkan penyakit yang berbahaya untuk kesehatan.

Daya tarik emosional yaitu dengan coba membangkitkan emosi positif atau negatif yang akan memotivasi komunikan. Daya tarik emosional dalam isi pesan yang terdapat pada bungkus rokok adalah daya tarik emosional negatif, yaitu mencoba untuk memberikan ancaman dan rasa takut perokok akan bahaya rokok, berdasarkan analisis format pesan tulisan dan gambar peringatan di atas, isi pesan dalam bungkus rokok ini memiliki daya tarik emosional yang dapat membangkitakan emosi perokok karena menggunakan jenis tulisan dan warna yang menarik perhatian perokok. Menurut Vinsensius Sitepu (2005:44) untuk menambah kesan emosional pada suatu pesan seorang komunikator dapat menambahkan gambar, karena gambar dapat lebih mudah diidentifikasi dan diingat, karena mewakili realitas visual manusia. Selain itu, gambar atau ilustrasi dapat memberikan sentuhan dan daya tarik terhadap penyampaian sebuah informasi dan ilustrasi yang baik dapat benar-benar mewakili substansi tulisan.

Daya tarik moral yaitu diarahkan pada perasaan komunikan tentang apa yang benar dan yang baik. Isi pesan tulisan dan gambar peringatan dalam bungkus rokok menunjukan bahwa merokok dapat menyebabkan penyakit yaitu kanker mulut, kanker tenggorokan, kanker paru-paru, berbahaya bagi anak, hingga dapat menyebabkan kematian. Pesan tulisan menjelaskan gambarperingatan dengan jelas, gambar peringatan pun menggambarakan realitas visual penyakita yang disebabkan oleh rokok pada manuasi. Sehingga, pesan dan tulisan gambar peringatan bahaya merokok tersebut sudah mengarahkan para perokok tentang yang baik dan benar yaitu menunjukan pada perokok bahwa rokok dapat menimbulkan penyakit berbahaya bagi kesehatan.

\section{Karakteristik Responden Penelitian}

Responden dalam penelitian ini adalah mahasiswa dan mahasiswi yang tergabung dalam Keluarga Teater Kampus Bogor (KTKB) yang anggotanya berasal dari perguruan tinggi yang ada di Kota Bogor, pada umumnya mahasiswa semester 1 sampai dengan 8.

Anggota dalam komunitas ini mempunyai usia yang bervariasi berada di antara usia 17 hingga 28 tahun. Dalam penelitian ini usia responden dikelompokkan berdasarkan kelompok usia antara 17 - 20 tahun, 21 - 24 tahun, 25 - 28 tahun. Data yang diperoleh dari hasil penelitian menunjukkan bahwa, jumlah perokok sebagian besar adalah mereka yang berusia 21 - 24 tahun sebanyak 22 orang (50\%), sisanya 17 - 20 tahun sebanyak 16 orang (36\%), kemudian $25-28$ tahun 6 orang (14\%). 
Tabel 4 Kerakteristik Responden Berdasarkan Usia

\begin{tabular}{lll}
\hline Kategori Usia & $\mathrm{N}$ & $\%$ \\
\hline $17-20$ tahun & 16 & 36 \\
$21-24$ tahun & 22 & 50 \\
$25-28$ tahun & 6 & 14 \\
\hline Total & 44 & 100 \\
\hline
\end{tabular}

Berdasarkan data tersebut di atas, sebanyak 33 orang (82\%) responden yang berusia antara 17 - 24 tahun, dimana usia 18-25 tahun merupakan masa stabilitas perilaku sangat rendah sehingga lebih mudah dikenai persuasi dibanding kelompok usia lainnya. Pada usia ini dimungkinkan seseorang lebih mudah dikenai persuasi dibanding kelompok usia lainnya.

Komposisi responden terdiri dari laki-laki dan perempuan, Dalam komunitas ini antara laki-laki dan perempuan harus saling bertukar pikiran dalam menciptakan keindahan seni. Pengaruh lingkungan dan interaksi intens dalam komunitas ini dapat diduga berpengaruh pada perilaku anggotanya. Kebiasaan merokok pada sebagian anggota komunitas ini dapat mempengaruhi anggota kelompok lainnya untuk menjadi perokok. Berdasarkan data hasil penelitian dapat diketahui bahwa dalam kelompok ini tidak hanya laki-laki yang merupakan perokok, tetapi juga terdapat perempuan yang perokok. Data hasil penilitian menunjukan bahwa sebanyak 84\% (37 orang) berjenis kelamin laki-laki dan $16 \%$ (7 orang) berjenis kelamin perempuan.

Tabel 5. Karakteristik Responden berdasarkan jenis kelamin.

\begin{tabular}{lll}
\hline Jenis kelamin & $\mathbf{n}$ & $\mathbf{\%}$ \\
\hline Laki-laki & 84 & 37 \\
Perempuan & 7 & 16 \\
\hline Total & 44 & 100 \\
\hline
\end{tabular}

uang saku atau uang jajan bulanan (1) kurang

Selanjutnya berdasarkan uang saku atau uang jajan bulanan perokok, responden dikelompokkan ke dalam empat kategori yaitu, dari Rp. 300.000, (2) Rp. 300.000 - Rp. 600.000, (3) Rp. 600.000 - Rp. 1.000 .000 dan (4) lebih besar Rp. 1.000 .000 perbulan.

Tabel 6 Karakteristik Responden berdasarkan uang saku setiap bulannya.

\begin{tabular}{lll}
\hline Kategori uang saku & N & \% \\
\hline$<$ Rp. 300.000 & 19 & 43 \\
Rp. 300.000-Rp. 600.000 & 11 & 25 \\
Rp. 600.000- Rp. Rp. 1.000 .000 & 7 & 16 \\
$\quad>$ Rp. 1.000 .000 & 7 & 16
\end{tabular}




\begin{tabular}{lll}
\hline Total & 44 & 100 \\
\hline
\end{tabular}

Jumlah uang saku responden perokok sebagian besar menyebar dikisaran kurang dari Rp.300.000 perbulan yaitu sebanyak 19 orang (43\%), kisaran Rp.300.000 sampai Rp.600.000 perbulan yaitu sebanyak 11 orang (25\%), kisaran Rp.600.000-Rp.1.000.000 perbulan dan lebih besar dari Rp. 1.000.000 perbulan masing-masing sebanyak 7 orang (16\%).

Sedangkan berdasarkan awal responden mulai merokok atau berapa lama ia menjadi perokok, menggambarkan apakah responden perokok dapat dikategorikan sudah kecanduan atau beru awal atau pertama kali mencoba mulai merokok. Dalam penelitian ini awal mulai respoden merokok atau berapa lama ia menjadi perokok, dikelompokkan ke dalam 4 (empat) kategori, yaitu kurang dari 6 (enam) bulan, $6-12$ bulan, $1-3$ tahun dan lebih dari 3 tahun sebagai perokok. Data hasil penelitian dapat dilihat pada tabel berikut.

Tabel 7. Karakteristik Responden berdasarkan awal mulai merokok

\begin{tabular}{lll}
\hline Kategori Mulai Merokok & $\mathbf{N}$ & $\mathbf{\%}$ \\
\hline$<6$ bulan & 1 & 2 \\
$6-12$ bulan & 3 & 7 \\
$1-3$ tahun & 7 & 16 \\
$>3$ tahun & 33 & 75 \\
\hline Total & 44 & 100 \\
\hline
\end{tabular}

Dapat diketahui persentase responden awal mulai merokok atau berapa lama mereka sudah menjadi perokok, data hasil penelitian menunjukkan bahwa sebagian besar sudah mulai merokok lebih dari 3 tahun, yaitu sebanyak 33 orang (75\%), 1-3 tahun 7 orang (16\%), 6-12 bulan sebanyak 3 orang (7\%) dan kurang dari 6 bulan yaitu 1 orang (2\%).
Uang saku diduga mempunyai hubungan dengan jumlah banyaknya rokok yang dihisap oleh responden. Jumlah responden perokok berdasarkan jumlah rokok yang dihisap setiap hari dibagi menjadi empat kategori yaitu kurang dari 4 batang, $4-6$ batang, $7-12$ batang dan lebih dari 12 batang setiap hari.

Tabel 8 Jumlah batang rokok yang dihisap dalam setiap hari

\begin{tabular}{lll}
\hline $\begin{array}{l}\text { Kategori Jumlah Rokok } \\
\text { yang dihisap }\end{array}$ & $\mathbf{N}$ & $\mathbf{\%}$ \\
\hline$<4$ batang & 5 & 11 \\
$4-6$ batang & 3 & 7 \\
$6-12$ batang & 23 & 52 \\
$>12$ batang & 13 & 30 \\
\hline Total & 44 & 100 \\
\hline
\end{tabular}

Berdasarkan Tabel 8 di atas dapat diketahui bahwa, presentase jumlah rokok yang dihisap dalam setiap hari oleh responden yang merupakan perokok sebagian besar yang menghabiskan 6 - 12 batang rokok sebanyak 23 orang (52\%), lebih dari 12 batang rokok sebanyak 13 orang (30\%), kurang dari 4 batang sebanyak 5 orang (11\%) dan presentase terkecil adalah $4-6$ batang sebanyak 3 orang (11\%). Kegiatan merokok dapat di lakukan kapan saja dan dimana saja sebagai suatu kebiasaan atau suasana yang 
dianggap perokok sebagai waktu yang nyaman atau enak untuk merokok. Dalam penelitian ini dikelompokan ke dalam lima kategori pada saat kapan saja yang sering dilakukan responden untuk merokok. Kategori waktu yang sering digunakan untuk merokok, adalah sebagai berikut, setiap habis makan, saat berkumpul dengan sesama perokok, pada saat mengerjakan tugas, dan pada saat sedang sendirian, dan pilihan lebih dari satu aktivita.

Tabel 9 Waktu yang digunakan untuk merokok

\begin{tabular}{|l|l|c|c|}
\hline No & \multicolumn{1}{|c|}{ Kategori jumlah waktu merokok } & N & \% \\
\hline 1 & Setiap habis makan & 3 & 7 \\
\hline 2 & Saat berkumpul dengan sesama perokok & 5 & 0 \\
\hline 3 & Pada saat sedang mengerjakan tugas & 0 & 7 \\
\hline 4 & Pada saat sedang sendiri & 3 & 75 \\
\hline 5 & Pada lebih dari satu aktivitas & 33 & 100 \\
\hline Total & & 44 & \\
\hline
\end{tabular}

Berdasarkan Tabel 9, dapat dijelaskan bahwa sebagian besar 33 orang $(75 \%)$ responden perokok, melakukan kegiatan merokok lebih dari satu aktivitas. Hal ini mengandung pengertian bahwa responden perokok sebagian besar melakukan aktivitas merokok tidak hanya pada waktu-waktu tertentu saja (adiksi). Berikutnya sebanyak 5 orang (11\%) responden perokok, merokok pada saat berkumpul dengan sesama perokok, dari penelitian yang didapat ada dua kategori yang persentasnya sama yaitu, sebanyak 3 orang (7\%) masing-masing responden perokok menghisap rokok setiap habis makan dan pada saat sedang sendirian. Tidak ada perokok yang

\section{Gambar dan Tulisan tentang Peringatan Bahaya Merokok}

Penempatan gambar dan tulisan peringatan bahaya merokok yang wajib dimuat pada setaip kemasan bungkus rokok, sebagai upaya pemerintah untuk menimbulkan rasa takut (fear arousing), bagi setiap orang yang melihatnya, baik bagi perokok maupun yang bukan perokok. Dengan peringatan bahaya merokok yang terdapat pada setiap kemasan bungkus rokok diharapkan agar orang yang melihatnya tumbuh kesadaran bahwa rokok sangat berbahaya bagi penggunanya (perokok aktif) maupun orang yang ada disekitarnya (perokok pasif). Dampak psikologis yang diharapkan dari peringatan bahaya merokok melakukan kegiatan merokoknya hanya pada saat sedang mengerjakan tugas saja.

Dengan kata lain tidak ada perokok yang hanya melakukan kegiatan merokok pada saat mengerjakan tugas saja. Namun demikian tidak berarti bahwa tidak ada perokok yang tidak melakukan kegiatan merokok pada saat sedang mengerjakan tugas, karena pada sebagian responden (75\%) melakukan aktivitas merokok pada lebih dari satu aktivitas, sebagian perokok juga merokok pada saat mengerjakan tugas. Dengan demikian dapat diartikan bahwa sebagian besar responden dapat dikategorikan sebagai prokok aktif atau bahkan dapat dikatakan kecanduan (adiksi).

tersebut diharapkan prokok dapat mengurangi atau bahkan berhenti mengkonsumsi rokok, dan bagi orang yang belum menjadi perokok tidak mencoba untuk mengkonsumsi rokok.

Ada 5 (lima) jenis gambar beserta tulisan bahaya merokok yang wajib ditempatkan dalam setiap kemasan bungkus rokok dan iklan rokok. Pada setiap kemasan bungkus rokok terdapat salah satu gambar dari kelima jenis gambar tersebut. Gambar peringatan bahaya merokok tersebut terdiri atas (1) gambar dengan tulisan "Merokok membunuhmu", (2) gambar dengan tulisan "Merokok dapat menyebabkan kanker tenggorokan", 
gambar dan tulisan "Merokok menyebabkan Kanker paru-paru dan bronkitis kronis", (4) gambar dan tulisan "Merokok menyebabkan kanker mulut", dan (5) gambar dan tulisan "Merokok dekat anak berbahaya bagi mereka". Gambar atau ilustrasi yang ditampilkan dengan tulisan peringatan bahaya merokok dimaksudkan untuk memperjelas maksud atau tujuan yang ingin disampaikan bahwa rokok sangat berbahaya dan mengerikan.

Frekuensi dan persepsi reponden melihat gambar dan tulisan peringatan bahaya merokok yang tercantum dalam kemasan bungkus rokok dapat dilihat pada tabel berikut.

Table 10 Gambar dan tulisan peringatan bahaya merokok yang sering dilihat.

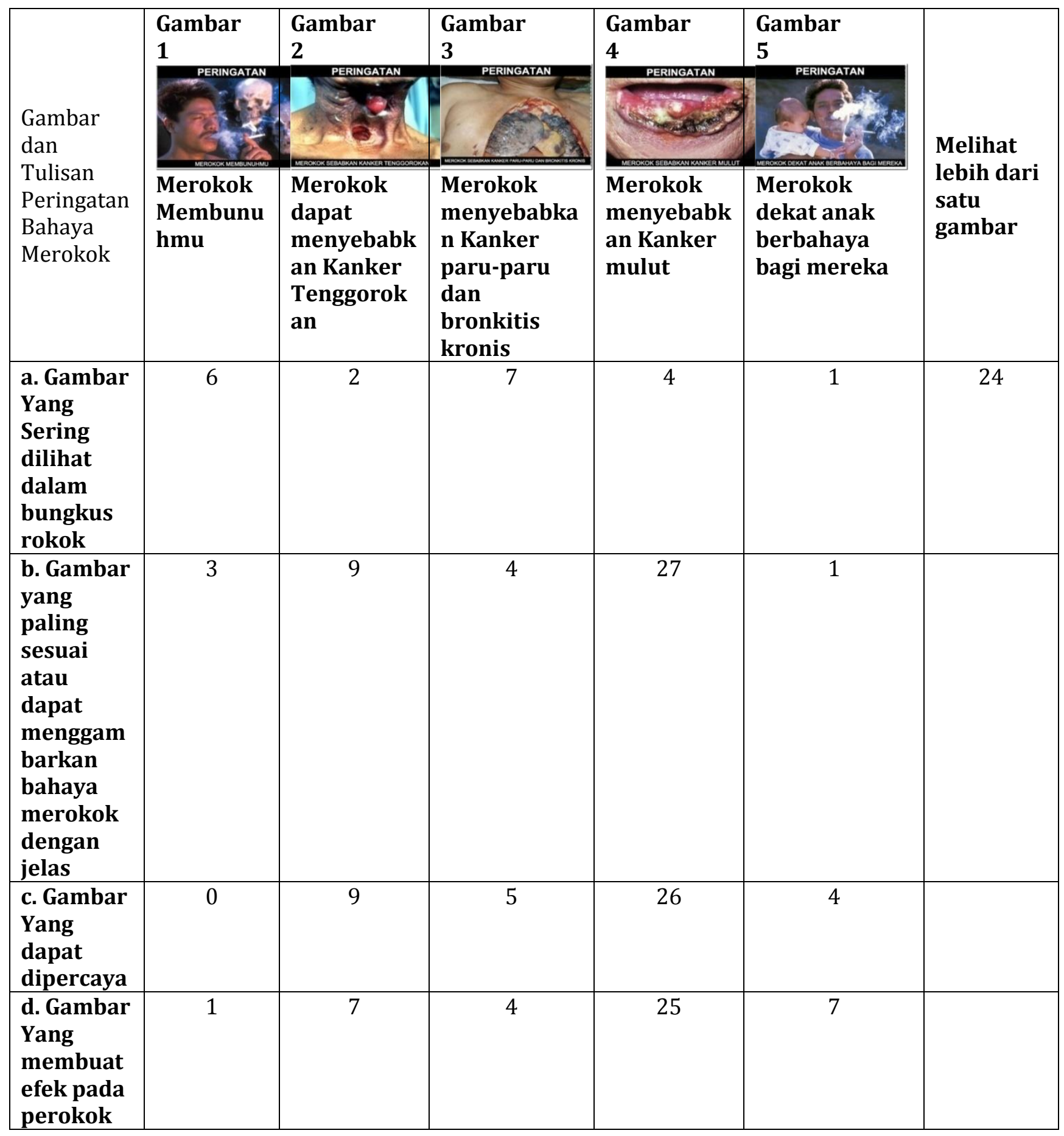


Gambar peringatan bahaya merokok yang sering dilihat dalam bungkus rokok

Berdasarkan Tabel 10, dapat diketahui bahwa sebanyak 24 (dua puluh empat) orang (54\%) reponden melihat lebih dari satu gambar peringatan bahaya merokok pada bungkus rokok, sebanyak 7 (tujuh) orang (16\%) hanya melihat gambar 3, sebanyak 6 (enam) orang (14\%) hanya melihat gambar 1 , sebanyak 4 (empat) orang (9\%) hanya melihat gambar 4, sebanyak 2 (dua) orang (5\%) hanya melihat gambar 2, dan hanya 1 (satu) orang (2\%) yang melihat gambar 5. Sehingga dapat disimpulkan bahwa sebagian besar responden perokok pernah melihat kelima gambar dan tulisan peringatan bahaya merokok pada kemasan bungkus rokok. Hal ini dapat diartikan bahwa perokok aktif (adiksi) atau yang sering melakukan kegiatan merokok umumnya pernah melihat semua jenis gambar dan tulisan peringatan bahaya merokok yang tercantum dalam bungkus rokok.

\section{Gambar peringatan bahaya merokok yang sesuai atau dapat menggambarkan bahaya merokok dengan jelas}

Berdasarkan Tabel 10, dari 5 (lima) jenis gambar perinagatan bahaya merokok yang terdapat dalam kemasan bungkus rokok, sebagian besar reponden, 27 (dua puluh tujuh) responden (61\%) memilih gambar nomor 4, yaitu "Merokok menyebabkan kanker mulut" adalah gambar yang paling sesuai menggambarkan bahaya merokok dengan jelas. Berikutnya 9 (sembilan) orang reponden (21\%) memilih gambar nomor 2, yaitu "Merokok dapat menyebabkan kanker tenggorokan", 4 (empat) orang responden (9\%) memilih gambar nomor 3, yaitu "Merokok menyebabkan Kanker paru-paru dan bronkitis kronis", 3 (tiga) orang responden (7\%) memilih gambar nomor 1, yaitu "Merokok membunuhmu", dan seorang responden (2\%) memilih gambar nomor 5, yaitu "Merokok dekat anak berbahaya bagi mereka". Persepsi responden terhadap gambar peringatan bahaya merokok yang dianggap sesuai dan jelas menggambarkan bahayanya tentu saja dapat dipengaruhi oleh pengalaman pribadi masing-masing reponden maupun suasana emosi dari masing-masing responden. Namun demikian persepsi sebagian besar responden $61 \%$ dapat menjelaskan bahwa gambar/ilustrasi peringatan bahaya merokok yang dianggap paling sesuai dapat menjelaskan bahaya merokok adalah gambar nomor nomor 4, yaitu "Merokok menyebabkan kanker mulut".

\section{Gambar peringatan bahaya merokok yang dapat dipercaya}

Tabel 10 menunjukkan bahwa dari 5 (lima) jenis gambar peringatan bahaya merokok yang terdapat dalam kemasan bungkus rokok, yang dipercaya berbahaya atau dapat menimbulkan bahaya penyakit oleh sebagian besar reponden, 26 (dua puluh enam) orang (59\%) adalah gambar nomor 4, yaitu "Merokok menyebabkan kanker mulut". Berikutnya sebanyak 9 (Sembilan) orang responden (21\%) memilih gambar nomor 2, yaitu "Merokok dapat menyebabkan kanker tenggorokan", 5 (lima) orang responden (11\%) memilih gambar nomor 3, yaitu "Merokok menyebabkan Kanker paru-paru dan bronkitis kronis", dan 4 (empat) orang responden (9\%) memilih gambar nomor 5, yaitu "Merokok dekat anak berbahaya bagi mereka". Tetapi tidak ada seorang responden pun yang memilih gambar nomor 1, yaitu "Merokok membunuhmu". Dengan demikian dapat disimpulkan bahwa hampir seluruh responden percaya bahwa merokok berbahaya bagi kesehatan dan lingkungannya, namun tidak percaya bahwa rokok dapat membunuh perokok.

\section{Gambar yang memberikan efek rasa takut}

Berdasarkan Tabel 10, dalam hal gambar peringatan bahaya merokok yang dapat menimbulkan rasa takut (fear arousing), dari 5 (lima) jenis gambar peringatan bahaya merokok, sebagian besar responden, yaitu sebanyak 25 (dua puluh lima) orang (57\%) memilih gambar nomor 4, yaitu "Merokok menyebabkan kanker mulut". Berikutnya sebanyak 7 (tujuh) orang (16\%) yang memilih gambar nomor 2, yaitu "Merokok dapat menyebabkan kanker tenggorokan", sebanyak 7 (tujuh) orang (16\%) yang memilih gambar nomor 5, yaitu "Merokok dekat anak berbahaya bagi mereka", 4 (empat) orang responden (9\%) 
memilih gambar nomor 3, yaitu "Merokok menyebabkan Kanker paru-paru dan bronkitis kronis", dan hanya seorang responden yang memilih gambar nomor 1, yaitu "Merokok membunuhmu". Dengan demikian dapat disimpulkan bahwa gambar peringatan bahaya merokok yang dapat menimbulkan rasa takut bagi sebagian besar responden perokok secara berturut-turut adalah peringatan bahaya merokok yang menggambarkan penyakit kanker mulut, berikutnya penyakit kanker tenggorokan dan membahayakan bagi lingkungan yang ada disekitar perokok, penyakit kanker paru-paru dan bronchitis kronis, serta rokok dapat menyebabkan kematian. Persepsi responden ini tentu sangat dipengaruhi oleh faktor psikologis dari masingmasing responden terhadap ilustrasi gambar yang paling menimbulkan rasa takut berdasarkan penglaman responden terhadap dampak rokok bagi penggunanya yang pernah mereka ketahui.

\section{Format Gambar}

Pada bagian ini akan dianalisis desain grafik bentuk dan tata letak penempatan pesan gambar peringatan bahaya merokok yang terdapat pada bungkus rokok yang meliputi, (1) tata letak gambar, (2) ukuran gambar, (3) tulisan pada pesan gambar, penggunaan warna, (4) kesesuaian gambar dengan tulisan. Analisis ini dilakukan untuk mengetahui persepsi responden terhadap grafis gambar dan tulisan pesan peringatan bahaya merokok pada kemasan bungkus rokok.

\section{Tata Letak Pesan Gambar}

Tata letak pesan grafis/gambar pada kemasan bungkus rokok yang mudah dilihat, sehingga setiap orang yang melihat kemasan bungkus rokok dapat melihat dengan jelas pesan gambar dan tulisan peringatan bahaya merokok.

Tabel 11. Posisi penempatan gambar peringatan bahaya merokok mudah dilihat.

\begin{tabular}{|l|c|c|c|}
\hline Jawaban Responden & F & x & f(x) \\
\hline Sangat Setuju & 10 & 5 & 50 \\
Setuju & 25 & 4 & 100 \\
Kurang setuju & 4 & 3 & 12 \\
Tidak Setuju & 3 & 2 & 6 \\
Sangat Tidak Setuju & 2 & 1 & 170 \\
\hline Total & 44 & & \\
\hline Skor Skala Likert $\sum \mathrm{f}(\mathrm{x}) / \mathrm{n}: 170 / 44=3,86$ & \multicolumn{2}{|l|}{} \\
\hline
\end{tabular}

Berdasarkan Tabel 11 di atas, dapat diketahui bahwa sebagian besar responden, yaitu sebanyak 25 orang (56\%) menyatakan setuju bahwa tata letak pesan gambar dalam bungkus rokok ini berada dalam posisi yang mudah dilihat dan. 10 orang (23\%) menyatakan Sangat setuju. Sedangkan, 4 orang $(10 \%)$ menyatakan kurang setuju, 3 orang $(7 \%)$ menyatakan tidak setuju, serta 2 orang (5\%) menyatakan sangat tidak setuju. Selanjutnya hasil penghitungan dengan menggunakan weight means score diperoleh angka penafsiran sebesar 3,86, berdasarkan kriteria penfasiran termasuk pada kategori baik. Maka dapat dinyatakan bahwa indikator tata letak pesan gambar, yaitu posisi penempatan gambar peringatan bahaya merokok pada kemasan bungkus rokok mudah dilihat. Hal ini mengandung makna bahwa tata letak pesan gambar peringatan bahaya merokok dalam bungkus rokok penempatannya sudah tepat.

\section{Ukuran gambar}

Proporsi dan ukuran gambar peringatan bahaya merokok pada kemasan bungkus rokok yang menarik dan mudah dilihat diharapkan dapat mengingatkan bahaya merokok bagi setiap orang yang melihat bungkus rokok. Dengan mudah dilihatnya isi pesan gambar 
peringatan bahaya merokok tersebut takut untuk merokok. diharapkan dapat membuat perokok merasa

Tabel 12 Gambar peringatan bahaya merokok proporsional dan dapat dilihat dengan jelas.

\begin{tabular}{|c|c|c|c|}
\hline Jawaban Responden & f & $\mathbf{X}$ & $f(x)$ \\
\hline Sangat Setuju & 11 & 5 & 55 \\
\hline Setuju & 20 & 4 & 80 \\
\hline Kurang setuju & 10 & 3 & 30 \\
\hline Tidak Setuju & 2 & 2 & 4 \\
\hline Sangat Tidak Setuju & 1 & 1 & 1 \\
\hline Total & 44 & & 170 \\
\hline
\end{tabular}

Berdasarkan Tabel 12 dapat dijelaskan bahwa sebanyak 20 orang $(45 \%)$ responden menyatakan setuju bahwa ukuran gambar dalam gambar peringatan bahaya merokok dapat dilihat dengan jelas dan sebanyak 11 orang (25\%) anggota perokok menyatakan sangat setuju. Sedangkan sebanyak 10 orang (23\%) menyatakan kurang setuju, 2 orang (5\%) menyatakan tidak setuju. dan 1 orang (1\%) menyatkan sangat tidak setuju . Berdasarkan hasil penghitungan dengan menggunakan weight means score diperoleh angka penafsiran sebesar 3,86, yang termasuk pada kategori baik. Maka dapat dinyatakan bahwa indikator ukuran gambar peringatan bahaya merokok pada bungkus rokok sudah cukup proporsional atau dapat dilihat dengan jelas.

\section{Tulisan pada pesan gambar}

Ukuran tulisan yang menjelaskan pesan gambar perigatan bahaya merokok pada bungkus rokok harus dapat dibaca dengan jelas agar orang yang melihatnya dapat dengan mudah memahami isi pesan gambar tersebut. Dengan tulisan yang menjelaskan pesan gambar peringatan bahaya merokok tersebut diharapkan setiap orang yang melihatnya dapat mengetahui dan merasa takut akan bahaya merokok tersebut.

Tabel 13 Tulisan pada gambar peringatan bahaya merokok dapat dibaca dengan jelas

\begin{tabular}{|l|c|c|c|}
\hline Jawaban Responden & F & X & f(x) \\
\hline Sangat Setuju & 10 & 5 & 50 \\
Setuju & 23 & 4 & 92 \\
Kurang setuju & 4 & 3 & 12 \\
Tidak Setuju & 5 & 2 & 10 \\
Sangat Tidak Setuju & 2 & 1 & 2 \\
\hline Total & 44 & & 154 \\
\hline Skor Skala Likert $\sum \mathrm{f}(\mathrm{x}) / \mathrm{n}: 154 / 44=3,5$ & \multicolumn{3}{|l}{} \\
\hline
\end{tabular}

Berdasarkan Tabel 13, dapat dijelaskan bahwa sebagian besar responden, yaitu sebanyak 23 orang (52\%) menyatakan setuju bahwa tulisan pada pesan gambar dalam bungkus rokok berada dalam posisi yang dapat dibaca dengan jelas dan sebanyak 10 orang (23\%) menyatakan sangat setuju. Sedangkan 5 orang (11\%) menyatakan tidak setuju, 4 orang (9\%) menyatakan kurang setuju, dan 2 orang (5\%) menyatakan sangat tidak setuju. Selanjutnya hasil penghitungan dengan menggunakan weight means score diperoleh angka penafsiran sebesar 3,5, yang berdasarkan kriteria penfasiran termasuk pada kategori baik. Maka dapat dinyatakan bahwa indikator tulisan yang menjelaskan pesan gambar peringatan bahaya merokok pada bungkus rokok dapat dibaca dengan jelas oleh sebagian besar orang yang melihatnya.

\section{Warna}

Salah satu hal yang dapat menjadi daya tarik pesan gambar adalah warna atau kombinasi 
warna yang dapat menarik perhatian setiap orang yang melihatnya. Kombinasi perpaduan warna gambar pesan peringatan bahaya merokok diharapkan dapat menarik perhatian dan memberikan kesan yang menakutkan bagi setiap orang yang melihatnya (fear arousing).

Tabel 14 Kombinasi perpaduan warna gambar peringatan bahaya merokok memeberikan rasa takut

\begin{tabular}{|c|c|c|c|}
\hline Jawaban Responden & $\mathbf{f}$ & $\mathbf{X}$ & $f(x)$ \\
\hline Sangat Setuju & 7 & 5 & 45 \\
\hline Setuju & 22 & 4 & 88 \\
\hline Kurang setuju & 7 & 3 & 21 \\
\hline Tidak Setuju & 6 & 2 & 12 \\
\hline Sangat Tidak Setuju & 2 & 1 & 2 \\
\hline Total & 44 & & 168 \\
\hline
\end{tabular}

Berdasarkan Tabel 14 di atas, dapat dijelaskan bahwa sebanyak 22 orang $(50 \%)$ responden menyatakan setuju dan 7 orang (16\%) menyatakan sangat setuju bahwa warna yang digunakan dalam himbauan yang berada pada bungkus rokok menarik perhatian dan menimbulkan rasa takut. Sedangkan 7 orang (16\%) menyatakan kurang setuju, 6 orang (14\%) menyatakan tidak setuju, dan sebanyak 2 orang (5\%) menyatakan sangat tidak setuju. Selanjutnya berdasakan hasil penghitungan dengan menggunakan weight means score diperoleh angka penafsiran sebesar 3,81, yang termasuk pada kategori baik. Maka dapat dinyatakan bahwa indikator perpaduan warna yang digunakan dalam himbauan bahaya merokok tersebut menarik perhatian dan menimbulkan rasa takut bagi sebagian orang yang melihatnya.

\section{Kombinasi gambar dan tulisan}

Kesesuaian antara pesan gambar dan tulisan peringatan bahaya merokok pada bungkus rokok akan memudahkan orang untuk memahami atau mengerti maksud isi pesan gambar tersebut. Kombinasi gambar dan tulisan yang secara jelas dapat memberikan makna terhadap isi pesan gambar tersebut serta diharapkan dapat menjelaskan bahaya yang ditimbulkan akibat merokok.

Tabel 15 Tulisan bahaya akibat merokok menjelaskan gambar peringatan bahaya merokok.

\begin{tabular}{|l|l|l|l|}
\hline Jawaban Responden & f & x & $\mathbf{f ( x )}$ \\
\hline Sangat Setuju & 6 & 5 & 30 \\
Setuju & 21 & 4 & 84 \\
Kurang setuju & 8 & 3 & 24 \\
Tidak Setuju & 6 & 2 & 12 \\
Sangat Tidak Setuju & 3 & 1 & 3 \\
\hline Total & 44 & & 153 \\
\hline Skor Skala Likert $\sum \mathrm{f}(\mathrm{x}) / \mathrm{n}: 153 / 44=3,47$ & \\
\hline
\end{tabular}

Berdasarkan Tabel 15 di atas, dapat dijelaskan bahwa sebagian besar responden yaitu 21 orang (48\%) menyatakan setuju dan 6 orang (14\%) menyatakan sangat setuju bahwa tulisan bahaya akibat merokok sangat tepat menjelaskan gambar peringatan bahaya merokok. Sedangkan 8 orang (18\%) menyatakan kurang setuju, 6 orang (14\%) menyatakan tidak setuju, serta sebanyak 3 orang (7\%) menyatakan sangat tidak setuju bahwa tulisan bahaya akibat merokok menjelaskan gambar peringatan bahaya merokok sangat tepat. Selanjutnya hasil penghitungan dengan menggunakan weight means score diperoleh angka penafsiran sebesar 3,47, yang termasuk pada kategori baik. Maka dapat dinyatakan bahwa indikator tulisan bahaya akibat merokok sudah tepat dapat menjelaskan gambar peringatan bahaya merokok.

\section{Isi Pesan}




\section{Daya Tarik Emosional}

Daya tarik emosional adalah daya tarik yang mencoba membangkitkan emosi positif atau negatif komunikan. Dalam himbauan pesan tulisan gambar peringatan bahaya merokok yang terdapat pada bungkus rokok ini memiliki daya tarik emosional yang negatif yaitu daya tarik yang dapat memberikan ancaman dan memberikan rasa takut (fear arousing) bagi yang melihatnya.

Tabel 16 Pesan tulisan dan gambar peringatan bahaya merokok membuat rasa takut untuk merokok

\begin{tabular}{|l|c|c|c|}
\hline Jawaban Responden & f & x & f(x) \\
\hline Sangat Setuju & 0 & 5 & 0 \\
Setuju & 18 & 4 & 72 \\
Kurang setuju & 11 & 3 & 33 \\
Tidak Setuju & 13 & 2 & 26 \\
Sangat Tidak Setuju & 2 & 1 & 2 \\
\hline Total & 44 & & \\
\hline Skor Skala Likert $\sum \mathrm{f}(\mathrm{x}) / \mathrm{n}: 133 / 44=3,02$ & \\
\hline
\end{tabular}

Berdasarkan Tabel 16 di atas, dapat dijelaskan bahwa sebanyak 18 orang (41\%) responden menyatakan setuju dan tidak ada yang menyatakan sangat setuju bahwa pesan tulisan dan gambar peringatan bahaya merokok pada bungkus rokok terkesan memberikan ancaman. Sedangkan 11 orang (25\%) menyatak kurang setuju, 13 orang (29\%) menyatakan tidak setuju, serta 2 orang (5\%) menyatakan sangat tidak setuju, bahwa pesan gambar peringatan bahaya merokok pada bungkus rokok terkesan memberikan ancaman. Berdasarkan hasil penghitungan dengan menggunakan weight means score diperoleh angka penafsiran sebesar 3,02, termasuk pada kategori sedang. Dengan demikian dapat dinyatakan bahwa indikator isi pesan gambar peringatan bahaya merokok yang terdapat pada bungkus rokok terkesan kurang memeberikan ancaman rasa takut untuk tidak merokok bagi sebagian responden.

\section{Daya Tarik Rasional}

Daya tarik rasional adalah daya tarik yang memberikan pertimbangan manfaat atau kerugian yang akan diperoleh berdasarkan argumentasi logis. Hal ini berhubungan dengan sejauhmana tulisan dan gambar peringatan bahaya merokok dapat menunjukan argumentasi logis bahwa rokok dapat berbahaya bagi kesehatan penggunanya dan orang yang berada disekitarnya.

Tabel 17. Pesan tulisan dan gambar peringatan bahaya merokok memberikan argumentasi logis bahwa rokok berbahaya bagi kesehatan

\begin{tabular}{|l|c|c|c|}
\hline Jawaban Responden & f & x & f(x) \\
\hline Sangat Setuju & 4 & 5 & 20 \\
Setuju & 25 & 4 & 100 \\
Kurang setuju & 9 & 3 & 27 \\
Tidak Setuju & 4 & 2 & 8 \\
Sangat Tidak Setuju & 2 & 1 & 2 \\
\hline Total & 44 & & 154 \\
\hline Skor Skala Likert $\sum \mathrm{f}(\mathrm{x}) / \mathrm{n}: 154 / 44=3,5$ & \\
\hline
\end{tabular}

Berdasarkan Tabel 17, dapat dijelaskan bahwa sebanyak 25 orang $(57 \%)$ responden menyatakan setuju dan 4 orang $(9 \%)$ menyatakan sangat setuju pesan gambar peringatan bahaya merokok yang ada pada bungkus rokok terkesan memberikan argumentasi logis bahwa rokok berbahaya bagi kesehata. Sedangkan 9 orang (20\%) menyatakan kurang setuju 4 orang (9\%) menyatakan tidak setuju, serta 2 orang atau $(5 \%)$ orang menyatakan sangat tidak setuju bahwa himbauan tersebut terkesan memberikan argumentasi logis bahwa rokok berbahaya bagi kesehatan. Hasil penghitungan 
dengan menggunakan weight means score diperoleh angka penafsiran sebesar 3,5, termasuk pada kategori baik. Maka dapat dinyatakan bahwa indikator isi pesan gambar peringatan bahaya merokok yang terdapat pada bungkus rokok memberikan argumentasi logis bagi sebagian besar responden bahwa rokok berbahaya bagi kesehatan.

\section{Daya Tarik Moral}

Daya tarik moral dimaksudkan untuk memberikan kesan baik atau buruk yang berhubungan dengan nilai-nilai yang dianut oleh komunikan. Sejauh mana pesan tulisan dan gambar peringatan bahaya merokok yang terdapat pada bungkus rokok dapat menimbulkan penilaian baik atau buruk bagi orang yang melihatnya.

Tabel 18 Pesan tulisan dan gambar peringatan bahaya merokok memeberikan kesan bahwa merokok tidak baik bagi kesehatan

\begin{tabular}{|l|c|c|c|}
\hline Jawaban Responden & f & X & f(x) \\
\hline Sangat Setuju & 8 & 5 & 40 \\
Setuju & 20 & 4 & 80 \\
Kurang setuju & 10 & 3 & 30 \\
Tidak Setuju & 4 & 2 & 8 \\
Sangat Tidak Setuju & 2 & 1 & 2 \\
\hline Total & 44 & & 160 \\
\hline Skor Skala Likert $\sum \mathrm{f}(\mathrm{x}) / \mathrm{n}: 160 / 44=3,63$
\end{tabular}

Berdasarkan Tabel 18, dapat dijelaskan bahwa sebanyak 20 orang $(45 \%)$ responden menyatakan setuju dan 8 orang (18\%) menyatakan sangat setuju bahwa pesan gambar yang ada pada bungkus rokok memeberikan kesan bahwa merokok tidak baik bagi kesahatan. Sedangkan 10 orang (23\%) menyatakan kurang setuju, 4 orang (9\%) menyatakan tidak setuju, serta sebanyak 2 orang (5\%) menyatakan sangat tidak setuju bahwa himbauan pesan tulisan dan gambar peringatan bahaya merokok memeberikan kesan bahwa merokok tidak baik bagi kesehatan. Hasil penghitungan dengan menggunakan weight means score diperoleh angka penafsiran sebesar 3,63, termasuk pada kategori baik. Maka dapat dinyatakan bagi sebagian besar responden menilai bahwa merokok tidak baik bagi kesehatan.

\section{Rekapitulasi Hasil Analisis Variabel Format dan Isi Pesan Gambar Peringatan Bahaya Rokok pada Bungkus Rokok}

Rekapitulasi hasil analisis terhadap variabel format dan isi pesan gambar peringatan bahaya merokok, yang meilupti dimensi format gambar da nisi pesan gambar dapat dilihat pada tabel berikut ini. 
Tabel 19 Rekapitulasi Hasil Analisis Variabel Format dan Isi Pesan gambar

\begin{tabular}{|c|c|c|c|c|}
\hline No & Dimensi dan Indikator & $\frac{\sum f(x)}{N}$ & $\begin{array}{l}\text { Rata- } \\
\text { Rata }\end{array}$ & Penafsiran \\
\hline \multicolumn{5}{|c|}{ A. Fromat Gambar } \\
\hline 1 & Tata Letak Pesan Gambar & 3,86 & \multirow{5}{*}{3,70} & \multirow{5}{*}{ Baik } \\
\hline 2 & Ukuran Gambar & 3,86 & & \\
\hline 3. & Tulisan pada Gambar & 3,50 & & \\
\hline 4. & Warna & 3,81 & & \\
\hline 5. & Kombinasi Gmbar dan Tulisan & 3,47 & & \\
\hline \multicolumn{5}{|c|}{ B. Isi dan Daya Tarik Pesan } \\
\hline 1. & Daya Tarrik Emosional & 3,02 & \multirow{3}{*}{3,38} & \multirow{3}{*}{ Sedang } \\
\hline 2. & Daya Tarik Rasional & 3,50 & & \\
\hline 3. & Daya Tarik Moral & 3,63 & & \\
\hline \multicolumn{2}{|c|}{ Jumlah keseluruhan dan rata-rata angka penafsiran } & 28,65 & 3,54 & Baik \\
\hline
\end{tabular}

Berdasarkan Tabel 19 dapat diambil kesimpulan bahwa format grafis Gambar peringatan bahaya merokok pada bungkus rokok sudah baik, penempatannya pada kemasan bungkus rokok pada posisi yang mudah dilihat, ukurannya proporsional, tulisan pada gambar menjelaskan gambar yang ditampilkan serta penggunaan warna yang sesuai dengan pesan gambar, walaupun kombinasi gambar dan tulisan tidak terlalu baik. Dapat dijelaskan bahwa tulisan yang menjelaskan gambar cukup jelas dan cukup mudah dibaca, tetapi terlalu kecil dan kurang menarik. Selanjutnya Isi pesan dan daya tarik pesan Gambar peringatan bahaya merokok pada bungkus rokok secaram umum termasuk kategori sedang. Dapat dijelaskan bahwa isi pesan gambar, memiliki daya tarik rasional dan daya tarik moral, yang mengandung pengertian bahwa isi pesan gambar tentang bahaya merokok bersifat rasional dan secara moral umumnya diakui merokok tidak baik bagi kesehatan maupun lingkungan. Namun demikian isi pesan gambar kurang mampu membangkitkan emosional perokok sehingga menimbulkan rasa takut bagi orang yang melihatnya.

\section{Analisis Variabel Perubahan Perilaku Perokok}

\section{Kognitif}

Efek kognitif adalah akibat yang timbul pada diri komunikan yang sifatnya informatif bagi dirinya. Efek kognitif ini membahas tentang bagaimana media dapat membantu khalayak dalam mempelajari informasi untuk mengembangkan keterampilan kognitif. Indikator yang diukur untuk efek kognitif dalam penelitian ini adalah pengetahuan dan pemahaman.

\section{Pesan tulisan dan gambar peringatan bahaya merokok menimbulkan kesadaran bahaya merokok}

Pesan tulisan dan gambar peringatan bahaya merokok pada bungkus rokok memberikan informasi tentang bahaya rokok sehingga diharapkan akan menimbulkan kesadaran bahwa rokok berbahaya bagi kesehatan. 
Tabel 20 Tulisan dan gambar peringatan bahaya merokok menyadarkan akan bahaya merokok

\begin{tabular}{|l|c|c|c|}
\hline Jawaban Responden & f & X & f(x) \\
\hline Sangat Setuju & 4 & 5 & 20 \\
Setuju & 20 & 4 & 60 \\
Kurang setuju & 12 & 3 & 36 \\
Tidak Setuju & 4 & 2 & 8 \\
Sangat Tidak Setuju & 4 & 1 & 4 \\
\hline Total & 44 & & \\
\hline Skor Skala Likert $\sum \mathrm{f}(\mathrm{x}) / \mathrm{n}: 128 / 44=2,90$ & \\
\hline
\end{tabular}

Berdasarkan Tabel 20 dapat dijelaskan bahwa sebanyak 20 orang $(45 \%)$ responden menyatakan setuju dan 4 orang $(9 \%)$ menyatakan sangat setuju bahwa pesan dan gambar peringatan bahaya merokok dalam bungkus rokok menyadarkan akan bahaya merokok. Sedangkan sebanyak 12 orang $(27 \%)$ menyatkan kurang setuju. Selanjutnya 4 orang (9\%) menyatakan tidak setuju dan sangat tidak setuju bahwa pesan dan gambar peringatan bahaya merokok dalam bungkus rokok menyadarkan akan bahaya merokok. Hasil penghitungan dengan menggunakan weight means score diperoleh angka penafsiran sebesar 2,90, termasuk pada kategori sedang. Maka dapat dinyatakan bahwa indikator pesan tulisan dan gambar peringatan bahaya merokok pada bungkus rokok menimbulkan kesadaran akan bahaya merokok hanya bagi sebagian responden. Dengan demikian informasi himbauan peringatan bahaya merokok tidak cukup efektif untuk menimbulkan kesadarn akan bahaya merokok.

\section{Tulisan dan gambar peringatan bahya merokok pada Bungkus Rokok memberikan pemahaman akan bahaya merokok}

Selain menyadari, memahami isi pesan gambar peringatan bahaya merokok sangat penting bagi komunikan, karena dengan paham terhadap isi pesan gambar peringatan bahaya merokok, diharapkan orang akan menghindari rokok atau bahkan berhenti merokok.

Tabel 21 Pesan tulisan dan gambar bahaya merokok mememberikan pemahaman akan bahaya merokok

\begin{tabular}{|l|c|c|c|}
\hline Jawaban Responden & f & X & f(x) \\
\hline Sangat Setuju & 8 & 5 & 40 \\
Setuju & 25 & 4 & 100 \\
Kurang setuju & 8 & 3 & 24 \\
Tidak Setuju & 2 & 2 & 4 \\
Sangat Tidak Setuju & 1 & 1 & 169 \\
\hline Total & 44 & & \\
\hline Skor Skala Likert $\sum \mathrm{f}(\mathrm{x}) / \mathrm{n}: 169 / 44=3,84$ & \\
\hline
\end{tabular}

Berdasarkan Tabel 21 dapat dijelaskan bahwa sebanyak 25 orang (57\%) responden setuju dan 8 orang (18\%) sangat setuju bahwa pesan tulisan dan gambar peringatan bahaya merokok memeberikan pemahaman akan bahaya merokok. Sedangkan 8 orang (18\%) kurang setuju 2 orang (5\%) menyatakan tidak setuju, serta 1 orang (2\%) menyatkan sangat tidak setuju bahwa pesan tulisan dan gambar peringatan bahaya merokok memeberikan 
pemahaman akan bahaya merokok. Selanjutnya hasil penghitungan dengan menggunakan weight means score diperoleh angka penafsiran sebesar 3,84, termasuk pada kategori baik. Maka dapat dinyatakan bahwa sebagian besar responden memahami bahwa rokok berbahaya bagi kesehatan.

\section{Afektif}

Efek afektif timbul bila ada perubahan apa yang dirasakan, disenangi atau dibenci khalayak. Efek ini ada hubungannya dengan emosi, sikap atau nilai. Perasaan setuju responden terhadap isi himbauan, dapat mengindikasikan pendapat responden sama dengan komunikator, bahwa merokok dapat berbahaya bagi kesehatan, dan responden dapat berusaha untuk menghindari merokok.

\section{Perasaan Takut}

Salah satu tujuan dari pesan tulisan dan gambar peringatan bahaya merokok pada bungkus rokok adalah agar perokok takut akan bahaya merokok. Sejauh mana pesan tulisan dan gambara peringatan bahaya merokok pada bungkus rokok berpengaruh terhadap sikap perokok untuk menghindari atau berhenti merokok karna takut akan bahaya merokok.

Tabel 22 Pesan tulisan dan gambar peringatan bahaya merokok menimbulkan rasa takut akan bahaya merokok

\begin{tabular}{|l|c|c|c|}
\hline Jawaban Responden & f & x & f(x) \\
\hline Sangat Setuju & 4 & 5 & 20 \\
Setuju & 16 & 4 & 64 \\
Kurang setuju & 14 & 3 & 42 \\
Tidak Setuju & 6 & 2 & 12 \\
Sangat Tidak Setuju & 4 & 1 & 4 \\
\hline Total & 44 & & \\
\hline Skor Skala Likert $\sum \mathrm{f}(\mathrm{x}) / \mathrm{n}: 142 / 44=3,2$ &
\end{tabular}

Berdasarkan Tabel 22 di atas, dapat dijelaskan bahwa sebanyak 16 orang (36\%) responden menyatakan setuju dan 4 orang (9\%) menyatakan sangat setuju dengan adanya pesan tulisan dan gambar peringatan bahaya merokok menimbulkan rasa takut akan bahaya merokok, sedangkan sebanyak 14 orang (32\%) menyatakan kurang setuju, sementara itu sebanyak 6 orang (14\%) menyatakan tidak setuju, sementara sebanyak 4 orang (9\%) menyatakan sangat tidak setuju dengan adanya pesan tulisan dan gambar peringatan bahaya merokok menimbulkan rasa takut akan bahaya merokok Hasil penghitungan dengan menggunakan weight means score diperoleh angka penafsiran sebesar 3,2 , termasuk pada kategori sedang. Maka dapat dinyatakan bahwa pesan tulisan dan gambar peringatan bahaya merokok tidak cukup efektif untuk memeberikan rasa takut bahaya akan merokok

\section{Perasaan Terancam}

Pesan tulisan dan gambar peringatan bahaya merokok pada bungkus rokok bertujuan agar orang yang melihat dan memebacanya akan merasa terancam dengan akibat penyakit yang ditimbulkan oleh rokok. Dengan merasa terancam oleh akibat bahaya merokok diharapkan orang akan bersikap untuk menghindari rokok atau akan berhenti untuk merokok.

Tabel 23 Pesan tulisan dan gambara peringatan bahaya merokok menimbulkan perasaan terancam oleh akibat bahaya merokok

\begin{tabular}{|l|c|c|c|}
\hline Jawaban Responden & f & X & f(x) \\
\hline Sangat Setuju & 5 & 5 & 25 \\
Setuju & 17 & 4 & 68 \\
Kurang setuju & 13 & 3 & 39 \\
Tidak Setuju & 7 & 2 & 14 \\
Sangat Tidak Setuju & 2 & 1 & 2 \\
\hline
\end{tabular}




\begin{tabular}{|l|l|c|}
\hline Total & 44 & \\
\hline Skor Skala Likert $\sum \mathrm{f}(\mathrm{x}) / \mathrm{n}: 148 / 44=3,36$ & \\
\hline
\end{tabular}

Berdasarkan Tabel 23 di atas, dapat dijelaskan bahwa sebanyak 17 orang (39\%) responden menyatakan setuju dan sebanyak 5 orang (11\%) menyatakan sangat setuju bahwa pesan tulisan dan gambara peringatan bahaya merokok menimbulkan perasaan terancam oleh akibat bahaya merokok. Sedangkan 13 orang (29\%) menyatakan kurang setuju 7 orang $(16 \%)$ mengatakan kurang setuju serta sebanyak 2 orang (5\%) menyatakan sangat tidak setuju bahwa pesan tulisan dan gambara peringatan bahaya merokok menimbulkan perasaan terancam oleh akibat bahaya merokok. Hasil penghitungan dengan menggunakan weight means score diperoleh angka penafsiran sebesar 3,36, termasuk pada kategori baik. Maka dengan demikian dapat dinyatakan bahwa pesan tulisan dan gambar peringatan bahaya merokok menimbulkan perasaan terancam akibat bahaya merokok pada sebagian responden.

\section{Behavioural}

Efek behavioural merujuk pada perilaku yang nyata yang dapat diamati. efek ini bersangkutan dengan niat, tekad, upaya, usaha yang cenderung menjadi suatu kegiatan atau tindakan.

\section{Membuat untuk tidak suka pada rokok}

Salah satu perubahan perilaku yang diharapkan dari pesan tulisan dan gambar peringatan bahaya merokok pada bungkus rokok adalah membuat perokok tidak suka pada rokok setelah melihat peringatan bahaya merokok pada bungkus rokok.

Tabel 24 Pesan tulisan dan gambar peringatan bahaya merokok membuat rasa tidak suka pada rokok

\begin{tabular}{|l|c|c|c|}
\hline Jawaban Responden & f & X & f(x) \\
\hline Sangat Setuju & 3 & 5 & 15 \\
Setuju & 8 & 4 & 32 \\
Kurang setuju & 17 & 3 & 51 \\
Tidak Setuju & 12 & 2 & 24 \\
Sangat Tidak Setuju & 4 & 1 & 4 \\
\hline Total & 44 & & 126 \\
\hline Skor Skala Likert $\sum \mathrm{f}(\mathrm{x}) / \mathrm{n}: 126 / 44=2,86$ & \\
\hline
\end{tabular}

Berdasarkan Tabel 24, dapat dijelaskan bahwa sebanyak 3 orang (7\%) reponden menyatakan sangat setuju dan 8 orang (18\%) menyatakan setuju bahwa setelah melihat pesan tulisan dan gambar peringatan bahaya merokok yang ada pada bungkus rokok responden menjadi tidak suka pada rokok. Sedangkan 17 orang (39\%) responden menyatakan kurang setuju 12 orang (27\%) menyatakan tidak setuju, serta sebanyak 4 orang atau (9\%) menyatakan sangat tidak setuju bahwa setelah pesan tulisan dan gambar peringatan bahaya merokok yang ada pada bungkus rokok responden menjadi tidak suka pada rokok. Hasil penghitungan dengan menggunakan weight means score diperoleh angka penafsiran sebesar 2,86, termasuk pada kategori sedang. Maka dengan demikian dapat dijelaskan bahwa hanya sebagian kecil responden yang menyatakan menjadi tidak suka pada rokok setelah melihat pesan tulisan dan gambar peringatan bahaya merokok yang terdapat pada bungkus rokok.

\section{Berusaha Berhenti Merokok}

Perubahan perilaku lainnya yang diharapkan setelah melihat dan membaca pesan tulisan dan gambar peringatan bahaya merokok yang terdapat pada bungkus rokok adalah agar orang yang belum mulai merokok tidak mulai merokok dan perokok akan berusaha berhenti merokok. 
Tabel 25 Pesan tulisan dan gambar peringatan bahaya merokok membuat perokok berhenti merokok

\begin{tabular}{|l|c|c|c|}
\hline Jawaban Responden & f & x & f(x) \\
\hline Sangat Setuju & 0 & 5 & 0 \\
Setuju & 11 & 4 & 44 \\
Kurang setuju & 16 & 3 & 48 \\
Tidak Setuju & 10 & 2 & 20 \\
Sangat Tidak Setuju & 7 & 1 & 119 \\
\hline Total & 44 & & \\
\hline Skor Skala Likert $\sum \mathrm{f}(\mathrm{x}) / \mathrm{n}: 119 / 44=2,70$
\end{tabular}

Berdasarkan Tabel 25 dapat dijelaskan bahwa sebanyak 11 orang $(25 \%)$ responden menyatakan setuju dan tidak ada yang menyatakan sangat setuju bahwa pesan tulisan dan gambar peringatan bahaya merokok membuat perokok berhenti merokok. Sedangkan 16 orang (36\%) responden menyatakan kurang setuju 10 orang (23\%) menyatakan tidak setuju serta sebanyak 7 orang (16\%) menyatakan sangat tidak setuju bahwa pesan tulisan dan gambar peringatan bahaya merokok membuat perokok berhenti merokok. Hasil penghitungan dengan menggunakan weight means score diperoleh angka penafsiran sebesar 2,70, termasuk pada kategori sedang. Maka dengan demikian dapat dijelaskan bahwa hanya sebagian kecil responden yang menyatakan pesan tulisan dan gambar peringatan bahaya merokok membuat perokok berhenti merokok.

\section{Tindakan untuk berhenti merokok dan tidak burkumpul dengan para perokok.}

Perubahan perilaku responden seelah melihat dan membaca pesan tulisan dan gambar peringatan bahaya merokok pada bungkus rokok selain berusaha untuk berhenti merokok diharapkan juga dapat menghindari untuk berkumpul dengan para perokok.

Tabel 26. Pesan tulisan dan gambar peringatan bahaya merokok membuat berhenti merokok dan tidak berkumpul dengan para perokok

\begin{tabular}{|l|c|c|c|}
\hline Jawaban Responden & f & x & f(x) \\
\hline Sangat Setuju & 1 & 5 & 5 \\
Setuju & 8 & 4 & 32 \\
Kurang setuju & 14 & 3 & 42 \\
Tidak Setuju & 9 & 2 & 18 \\
Sangat Tidak Setuju & 12 & 1 & 12 \\
\hline Total & 44 & & 109 \\
\hline Skor Skala Likert $\sum \mathrm{f}(\mathrm{x}) / \mathrm{n}: 109 / 44=2,47$
\end{tabular}

Berdasarkan Tabel 26 dapat dijelaskan bahawa sebanyak 1 orang (2\%) menyatakan sangat setuju dan 8 orang (18\%) menyatakan setuju bahwa Pesan tulisan dan gambar peringatan bahaya merokok membuat berhenti merokok dan tidak berkumpul dengan para perokok. Sedangkan 14 orang (36\%) responden menyatakan kurang setuju, 12 orang $(27 \%)$ menyatakan sangat tidak setuju, serta 9 orang $(21 \%)$ menyatakan tidak setuju bahwa pesan tulisan dan gambar peringatan bahaya merokok membuat berhenti merokok dan tidak berkumpul dengan para perokok. Hasil penghitungan dengan menggunakan weight means score diperoleh angka penafsiran sebesar 2,47, termasuk pada kategori buruk. 
Maka dengan demikian dapat dinyatakan bahwa pesan tulisan dan gambar peringatan bahaya merokok tidak cukup berpengaruh untuk membuat berhenti merokok dan tidak berkumpul dengan para perokok.

Berdasarkan hasil analisis terhadap perubahan prilaku akibat pesan tulisan dan gambar peringatan bahaya merokok pada bungkus rokok tidak cukup signifikan berpengaruh pada perubahan sikap dan prilaku tidak suka rokok, berhenti merokok dan menghindari berkumpul dengan para perokok.

\section{Rekapitulasi Hasil Analisis Variabel Perilaku Perokok}

Rekapitulasi hasil analisis terhadap variabel Perilaku Perokok, yang meilupti dimensi kognitif, afektif, dan behavioral dapat dilihat pada tabel berikut ini.

Tabel 27 Rekapitulasi Hasil Analisis Variabel Perilaku Perokok

\begin{tabular}{|c|c|c|c|c|}
\hline No & Dimensi dan Indikator & $\frac{\sum f(x)}{N}$ & $\begin{array}{l}\text { Rata- } \\
\text { Rata }\end{array}$ & Penafsiran \\
\hline \multicolumn{5}{|c|}{ A. Kognitif } \\
\hline 1 & Kesadaran akan bahaya rokok & 2,90 & \multirow{2}{*}{3,37} & \multirow{2}{*}{ Sedang } \\
\hline 2 & Pemahaman akan bahaya rokok & 3,84 & & \\
\hline \multicolumn{5}{|c|}{ B. Afektif } \\
\hline 1. & Perasaan takut & 3,20 & \multirow{2}{*}{3,28} & \multirow{2}{*}{ Sedang } \\
\hline 2. & Perasaan terancam & 3,36 & & \\
\hline \multicolumn{5}{|c|}{ C. Behavioral } \\
\hline 1. & Tidak suka pada rokok/ menghindari rokok & 2,86 & \multirow{3}{*}{2,68} & \multirow{3}{*}{ Buruk } \\
\hline 2. & Berhenti merokok & 2,70 & & \\
\hline 3. & Tidak berkumpul dengan prokok & 2,47 & & \\
\hline \multicolumn{2}{|c|}{ Jumlah keseluruhan dan rata-rata angka penafsiran } & 21,33 & 3,05 & Sedang \\
\hline
\end{tabular}

Berdasarkan Tabel 27 dapat diambil kesimpulan bahwa efek kognitif dari isi pesan tulisan dan gambar peringatan bahaya merokok pada bungkus rokok berlum mampu menumbuhkan kesadaran akan bahaya merokok, walaupun pesan peringatan bahaya merokok tersebut dapat memberikan pemahaman akan bahaya merokok. Dengan demikian pemahaman terhadap isi pesan peringatan bahaya merokok tidak serta merta dapat menumbuhkan kesadaran akan bahaya merokok, sehingga banyak perokok tidak berkeinginan untuk mengubah perilakunya.
Demikian halnya dengan efek afektif dari isi pesan tulisan dan gambar peringatan bahaya merokok pada bungkus rokok berlum mampu menumbuhkan rasa takut dan perasaan terancam. Hal ini mengandung pengertian bahwa walaupun mereka, tahu dan paham akan bahaya merokok dan pesan gambar yang memberikan kesan menakutkan (fear arousing) akibat bahaya merokok, tapi belum mampu menunjukkan sikap takut dan terancam oleh akibat bahaya merokok. Demikian halnya dengan efek behavioral dari isi pesan tulisan dan gambar peringatan 
bahaya merokok pada bungkus rokok belum mampu memberikan efek tidak suka pada rokok dan menghindari rokok, berhenti merokok dan menghindari pergaulan dengan orang-orang perokok.

Dengan demikian dapat disimpulkan bahwa format dan isi pesan gambar peringatan bahaya merokok yang diekeluarkan oleh pemerintah pada setiap bungkus rokok dan iklan rokok, namun belum mampu mengubah perilaku perokok untuk menjadi tidak suka pada rokok, behenti merokok dan menghindar bergaul dengan perokok. Hal ini menunjukkan bahwa himbauan ataupun peringatan bahaya merokok tidak mempu mengubah perilaku pecandu rokok (adiksi) untuk berhenti merokok, sehingga untuk mengurangi bahkan menghentikan kebiasaan merokok selain himbauan pengringatan bahaya merokok juga harus diikuti dengan kebijakan-kebijakan pemerintah lainnya yang dapat membatasi ruang gerak perokok, sehingga diharapkan secara bertahap pecandu rokok dapat mengurangi kegiatan merokoknya dan pada akhirnya dapat berhenti merokok.

\section{Analisis Hubungan antara Variabel Himbauan pesan gambar peringatan bahaya merokok dan Variabel Perubahan Perilaku Perokok.}

Analisis Hubungan himbauan pesan gambar peringatan bahaya merokok pada bungkus rokok dan perubahan perilaku perokok, dengan menggunakan indikator sebagai berikut ; variabel pesan tulisan dan gambar peringatan bahaya merokok terdiri atas indikator, 1) tata letak pesan gambar, 2) ukuran gambar, 3) tulisan pesan gambar, 4) warna, 5) kombinasi gambar dan tulisan. Selanjutnya variabel perubahan prilaku terdiri atas indikator 1) menyadari, 2) paham, 3) takut, 4) terancam, 5) sikap, 6) keputusan, dan 7) tindakan. Berdasarkan uji kolerasi Rank Spearmans dengan alat bantu aplikasi SPSS For Windows Versi 20. Sebagaimana dapat dilihat pada Tabel 27 berikut ini. 
Tabel 28 Koefisien korelasi hubungan antara variabel himbauan pesan gambar peringatan bahaya merokok dan variabel perubahan perilaku perokok

\begin{tabular}{|c|c|c|c|c|c|c|c|}
\hline $\begin{array}{l}\begin{array}{r}\text { Variabel } \\
\text { prilaku }\end{array} \\
\text { Variabe } \\
\text { pesan }\end{array}$ & $\begin{array}{l}\text { Kesadaran } \\
\text { bahaya } \\
\text { merokok }\end{array}$ & $\begin{array}{l}\text { Pemahaman } \\
\text { bahaya } \\
\text { merokok }\end{array}$ & $\begin{array}{l}\text { Perasaan } \\
\text { takut }\end{array}$ & $\begin{array}{l}\text { Perasaan } \\
\text { terancam }\end{array}$ & $\begin{array}{l}\text { Sikap } \\
\text { tidak } \\
\text { suka } \\
\text { pada } \\
\text { rokok }\end{array}$ & $\begin{array}{l}\text { Keputus- } \\
\text { an } \\
\text { berhenti } \\
\text { merokok }\end{array}$ & $\begin{array}{l}\text { Tindakan } \\
\text { untuk tidak } \\
\text { berkumpul } \\
\text { dengan } \\
\text { perokok }\end{array}$ \\
\hline \multicolumn{8}{|l|}{$\begin{array}{l}\text { Format } \\
\text { pesan }\end{array}$} \\
\hline $\begin{array}{l}\text { Tata letak } \\
\text { pesan } \\
\text { Gambar }\end{array}$ & 0,198 & 0,280 & 0,193 & 0,183 & 0,272 & 0,101 & $-0,072$ \\
\hline $\begin{array}{l}\text { Ukuran } \\
\text { Gambar }\end{array}$ & 0,287 & $0,386^{* *}$ & $-0,126$ & $-0,088$ & 0,21 & 0,238 & $-0,057$ \\
\hline $\begin{array}{l}\text { Tulisan } \\
\text { pesan } \\
\text { Gambar }\end{array}$ & $0,485^{* *}$ & $0,354^{*}$ & $0,316^{*}$ & $0,351^{*}$ & $0,302^{*}$ & 0,247 & 0,135 \\
\hline Warna & 0,232 & $0,404^{*}$ & $0,356^{*}$ & 0,291 & 0,142 & 0,250 & 0,102 \\
\hline $\begin{array}{l}\text { Kombinasi } \\
\text { Gambar } \\
\text { dan } \\
\text { Tulisan } \\
\end{array}$ & $0,314^{*}$ & $0,430^{* *}$ & 0,178 & 0,110 & $0,299^{*}$ & 0,225 & 0,216 \\
\hline \multicolumn{8}{|l|}{ Isi pesan } \\
\hline $\begin{array}{l}\text { Daya tarik } \\
\text { Emosional }\end{array}$ & $0,396^{* *}$ & 0,069 & $0,502^{* *}$ & $0,458^{* *}$ & $0,556^{* *}$ & $0,631^{* *}$ & $0,405^{* *}$ \\
\hline $\begin{array}{l}\text { Daya tarik } \\
\text { Rasional }\end{array}$ & $0,476^{* *}$ & 0,196 & $0,341^{*}$ & $0,389^{* *}$ & $0,371^{*}$ & $0,401^{* *}$ & 0,084 \\
\hline $\begin{array}{l}\text { Daya tarik } \\
\text { Moral }\end{array}$ & $0,397^{* *}$ & $0,575^{* *}$ & $0,402^{* *}$ & $0,361^{*}$ & 0,279 & $0,397^{* *}$ & 0,216 \\
\hline
\end{tabular}

Sumber : Hasil Penghitungan SPSS

Keterangan : * berhubungan nyata pada tarf 0,01

** berhubungan sangat nyata 0,01

\section{Analisis Hubungan Format Pesan Gambar Peringatan Bahaya Merokok dan Perubahan Perilaku}

Berdasarkan Tabel 27 di atas, dapat dijelaskan hubungan antara variabel himbauan pesan peringatan bahaya merokok dengan aspek kognitif, afektif dan behevioral untuk masingmasing indikator adalah sebagi berikut.
1) Ukuran gambar pesan peringatan bahaya merokok mempunyai hubungan sangat nyata dengan pemahaman terhadap bahaya merokok dengan koefisien kolerasi sebesar 0,386**. Sedangkan indikator ukuran gamba pesan peringatan bahaya merokok tidak menujukan adanya hubungan yang nyata dengan indikator lainnya dari variabel prilaku, yaitu 
kesadaran bahaya merokok, perasaan takut, perasaan terancam, sikap tidak suka pada rokok, keputusan untuk berhenti merokok serta tidak berkumpul dengan para perokok.

2) Tulisan pesan gambar peringatan bahaya merokok mempunyai hubungan sangat nyata dengan kesadaran bahaya merokok dengan koefisien kolerasi sebesar 0,485**, dan berhubungan nyata dengan pemahaman bahaya merokok $\left(0,354^{*}\right)$, perasaan takut $\left(0,316^{*}\right)$, perasaan terancam $\left(0,351^{*}\right)$, serta prilaku tidak suka pada rokok $\left(0,302^{*}\right)$. Sedangkan indikator tulisan pesan gambar peringatan bahaya merokok tidak menujukan adanya hubungan yang nyata dengan indikator lainnya dari variabel prilaku, yaitu keputusan untuk berhenti merokok dan tidak berkumpul dengan para perokok.

3) Warna gambar peringatan bahaya merokok mempunyai hubungan nyata dengan pemahaman bahaya merokok $\left(0,404^{*}\right)$, dan perasaan takut $\left(0,356^{*}\right)$. Sedangkan indikator warna gambar pesan peringatan bahaya merokok tidak menujukan adanya hubungan yang nyata dengan indikator lainnya dari variabel prilaku, yaitu kesadaran bahaya merokok, perasaan terancam, sikap tidak suka pada rokok, keputusan untuk berhenti merokok serta tidak berkumpul dengan para perokok.

4) Kombinasi gambar dan tulisan peringatan bahaya merokok mempunyai hubungan sangat nyata dengan pemahaman terhadap bahaya merokok koefisien kolerasi sebesar 0,430**, dan berhubungan nyata dengan kesadaran bahaya merokok $\left(0,314^{*}\right)$, dan prilaku tidak suka pada rokok $(0,299 *)$. Sedangkan indikator kombinasi gambar dan tulisan peringatan bahaya merokok tidak menujukan adanya hubungan yang nyata dengan indikator lainnya dari variabel prilaku, yaitu perasaan takut, perasaan terancam, sikap tidak suka pada rokok, keputusan untuk berhenti merokok serta tidak berkumpul dengan para perokok.

\section{Analisis Hubungan Isi Pesan gamba peringatan dan Perubahan Perilaku perokok}

Berdasarkan Tabel 27 dijelaskan hubungan antara variabel hubungan isi pesan gambara peringatan bahaya merokok pada bungkus rokok dan perubahan prilaku perokok dengan aspek daya tarik emosional, rasional dan moral untuk masing-masing indikator adalah sebagi berikut

1) Daya tarik emosional peringatan pesan tulisan dan gambar peringatan bahaya merokok mempunyai hubungan yang sangat nyata dengan kesadaran bahaya merokok $\left(0,396^{* *}\right)$, perasaan takut $\left(0,502^{* *}\right)$, perasaan terancam $\left(0,458^{* *}\right)$, tidak suka pada rokok $\left(0,556^{* *}\right)$, berhenti merokok $\left(0,631^{* *}\right)$, serta tindakan untuk tidak berkumpul dengan perokok $\left(0,405^{* *}\right)$. Sedangkan indikator daya tarik emosional gambar dan tulisan peringatan bahaya merokok tidak menujukan adanya hubungan yang nyata dengan indikator lainnya dari variabel prilaku, yaitu pemahaman bahaya merokok.

2) Daya tarik rasional peringatan pesan tulisan dan gambar peringatan bahaya merokok mempunyai hubungan yang sangat nyata dengan kesadaran bahaya merokok $\left(0,476^{* *}\right)$, perasaan terancam $\left(0,389^{* *}\right)$, serta berhenti merokok $\left(0,401^{* *}\right)$ dan berhubungan nyata dengan perasaan takut $\left(0,341^{*}\right)$, dan tidak suka pada rokok (371*),Sedangkan indikator daya tarik rasional gambar dan tulisan peringatan bahaya merokok tidak menujukan adanya hubungan yang nyata dengan indikator lainnya dari variabel prilaku, yaitu pemahaman bahaya merokok dan sikap ntuk tidak berkumpul dengan para perokok.

3) Daya tarik moral peringatan pesan tulisan dan gambar peringatan bahaya merokok mempunyai hubungan yang sangat nyata dengan kesadaran bahaya merokok $\left(0,397^{* *}\right)$, pemahaman bahaya merokok $\left(0,575^{* *}\right)$, perasaan terancam $\left(0,389^{* *}\right)$, serta berhenti merokok $\left(0,401^{* *}\right)$ dan berhubungan nyata dengan perasaan terancam $\left(0,361^{*}\right)$. Sedangkan indikator daya tarik moral peringatan gambar dan tulisan bahaya merokok tidak menujukan 
adanya hubungan yang nyata dengan indikator lainnya dari variabel prilaku, yaitu suka pada rokok dan sikap utuk tidak berkumpul dengan para perokok.

\section{Analisis Hubungan antara Himbauan Pesan Gambar Pringatan Bahaya Merokok pada}

\section{Bungkus Rokok dan Perubahan Perilaku Perokok}

Analisis hubungan antara himbauan pesan gambar peringatan bahaya merokok pada bungkus rokok dengan perubahan perilaku perokok berdasarkan uji statistik korelasi Rank Spearmans dengan alat bantu SPSS For Windows Versi 20.

Tabel 29. Hasil uji korelasi antara himbauan pesan gambar pringatan bahaya merokok pada bungkus rokok dengan perubahan perilaku perokok

Correlations

\begin{tabular}{|ll|r|r|}
\hline & & Himbauan Pesan & \multicolumn{2}{l|}{$\begin{array}{l}\text { Perubahan } \\
\text { perilaku }\end{array}$} \\
\hline Himbauan Pesan & Correlation Correlation & 1,000 & $500^{* *}$ \\
Gambar & Sig. (2-tailed) &. &, 001 \\
& $\mathrm{~N}$ & 44 & 44 \\
\hline Perubahan perilaku & Correlation Correlation & $500^{* *}$ &, 001 \\
& Sig. (2-tailed) & 44 &. \\
& $\mathrm{~N}$ & 4,000 \\
\hline
\end{tabular}

Berdasarkan Tabel 28 dapat diketahui koefisien korelasi Rank Spearmans hubungan antara variabel himbauan pesan tulisan dan gambar peringatan bahaya merokok pada bungkus rokok dengan variabel perubahan perilaku perokok adalah sebesar 0,500**. Dengan demikian dapat disimpulkan bahwa terdapat hubungan yang sangat nyata diantara kedua variabel penelitian tersebut, walaupun berdasarkan interpretasi terhadap koefisien korelasi tingkat hubunganya termasuk pada kategori sedang. Angka koefisien korelasi positif menunjukan hubungan yang positif.

Untuk menentukan diterima atau ditolaknya hipotesis penelitian, maka dilakukan pengujian signifikan koefisien korelasi dengan rumus uji t yaitu:
Nilai $t_{\text {hitung }}=3,735$ kemudian dibandingkan dengan harga $t_{\text {tabel }}$ untuk menentukan tingkat signifikansi uji dua pihak. Dengan demikian, $t_{\text {hitung }}>t_{\text {tabel, }}$ yaitu $3,735>2,018$, sehingga Ho ditolak dan $\mathrm{Ha}$ diterima, dengan daerah penerimaan Ha sebagaimana dapat dilihat pada kurva pada Gambar 2 berikut ini.

Selanjutnya untuk mengetahui besarnya pengaruh variabel himbauan pesan tulisan dan gambar peringatan bahaya merokok pada bungkus rokok terhadap variabel perubahan perilaku perokok dilakukan uji koefisien determinasi (Kd). Dengan demikian besarnya kontribusi variabel pesan tulisan dan gambar peringatan bahaya merokok pada bungkus rokok terhadap perubahan perilaku perokok adalah sebesar $25 \%$, dan kontribusi faktor lain (faktor epsilon) adalah sebesar 75\%. 


\section{KESIMPULAN DAN SARAN}

\section{Kesimpulan}

1. Dalam penelitian ini, ILM yang terdapat dalam bungkus rokok menggunakan desain grafis dengan format, huruf atau font Calibri dengan ukuran 12 dengan spasi satu atau single, tulisan tersebut menggunakan warna putih dengan dasar berwana hitam. Selain itu, himbauan tersebut diletakkan di bawah gambar peringatan, untuk gambar peringatan mempunyai ukuran $5 \times 3,5 \mathrm{~cm}$ dengan tampilan gambar peringatan menggambarakan realitas visual penyakit yang disebabkan oleh rokok. Warna gambar peringatan dalam bungkus rokok terlihat begitu menarik dengan perpaduan warna yang seperti gambar aslinya atau gambar yang disebabkan oleh rokok. Sehingga, isi pesan tulisan gambar peringatan bahaya merokok tersebut sudah mengarahkan para perokok tentang yang baik dan benar yaitu menunjukan pada perokok bahwa rokok dapat menimbulkan penyakit berbahaya bagi kesehatan.

2. Dalam penelitian ini, menurut anggota perokok pesan tulisan dan gambar peringatan dalam posisi yang mudah dilihat, ukuran gambar dan kombinasi warna yang digunakan dalam bungkus rokok sangat menarik. Sementara itu, tulisan dan kombinasi gambar tulisan atau tulisan yang digunakan dapat dibaca dengan jelas. Tanggapan responden mengenai isi pesan adalah isi pesan dalam bungkus rokok sudah jelas, dan terkesan sesuai dengan fakta bahwa merokok dapat menyebabkan

\section{DAFTAR PUSTAKA}

Arifin A. 2003. Komunikasi politik paradigmapolitik-aplikasi-stategi-dan komunikasi politik indonesia. Jakarta : balai pustaka.

Chaeruman I. 2008, Modul Mata Kuliah Sejarah Media Massa. [tidak dipublikasikan].

Effendy OC. 2006. Teori dan Praktik ilmu Komunikasi. Bandung : Resdakaya.

Effendy. 2003. Ilmu, Teori dan Filsafat Komunikasi. Bandung: PT CitraAditya Bakti. penyakit untuk perokok dan orang lain untuk pemahaman dan rasa menyadari menurut anggota perokok, mereka menyadari dan memahami bahwa rokok berbahaya bagi kesehatan, untuk perasaan takut dan terancam anggota perokok merasa terancam dengan bahaya merokok, namun dengan adanya pesan tulisan dan gambar peringatan bahaya merokok mereka masih merasa ragu-ragu bahwa isi pesan tulisan dan gambar peringatan bahaya merokok membuat mereka tidak suka pada rokok atau berhenti merokok.

3. Dalam penelitian ini terdapat hubungan yang positif sebesar $(p>0,01)$ dengan kategori hubungan tinggi, dengan $\mathrm{T}_{\text {hitung }}>$ $\mathrm{T}_{\text {tabel }}(3,735>2,018)$, Maka ada hubungan yang signifikan antara himbauan pesan tulisan dan gambar peringatan bahaya merokok dalam bungkus rokok serta perubahan perilaku perokok dengan nilai kontribusi korelasi sebesar $25 \%$ dan kontribusi faktor lain sebesar $75 \%$.

\section{Saran}

1. Pemerintah hendaknya melakukan sosialisai tentang bahaya rokok di setiap generasi muda dan dewasa, tentang bahaya akan merokok dan berdampak pada kesehatan.

2. Pemerintah hendaknya memformulasikan ketentuan iklan rokok baik cetak maupun elektronik, sehingga dapat mengurangi konsumsi merokok.

3. Untuk penelitian selanjutnya, disarankan peneliti melakukan penelitian kulitatif tentang pengaruh pesan dan gambar peringatan bahaya merokok terhadap perubahan prilaku perokok.

Graham D. 2000. The Designer's Toolkit 2000 Colour Palette Swatches' ilex 2008 warna adalah fundamental untuk semua desain.

Kusmana, D. 2003. Rokok dan Kesehatan Jantung. Pusat Jantung Harapan Kita.Tidak diterbitkan.

Margono NSM. 2008, Sikap Khalayak Sasaran Atas ILM di Televisi (Studi pada Program Pengalihan Minyak Tanah ke Elpiji tahun 2007). [Skripsi]. Depok : Universitas Indonesia.

Moeleong LJ 2001. Metode Penelitian Kualitatif. Bandung : PT Remaja Rosdakarya. 
Mulyana D. 2005. Ilmu Komunikasi Suatu Pengantar. Bandung : Remaja Rosdakarya.

Rakhma J . 2001. Psikologi Komunikasi, Edisi Revisi, Bandung, Remaja Rosdakarya

Rakhmat J. 2005, Psikologi Komunikasi, Cet. ke23 Bandung: $\quad$ Remaja Rosdakarya.

Setianingsih E. 2006, Hubungan Antara Himbauan pesan gambar peringatan Dalam Bungkus Rokok Dan Perubahan Perilaku Perokok. (Studi pada Mahasiswa Program studi Ilmu Komunikasi Fakultas Ilmu Sosial, Ilmu Politik dan Ilmu Komunikasi). [Skripsi]. Bogor : Universitas Djuanda.

Sachar A\& Yan YS. 2000. Tinjauan Desain. Bandung: ITB.

Sitepu V. 2005, Panduan Mengenai Design Grafis, Jakarta: Elex Media Komputindo.

Sugiyono, 2008. Metode Penelitian Kunatitatif Kualitatif dan R\&D. Bandung : Alfabeta.

Sugiyono. 2010, Statistika Untuk Penelitian, Cet ke-16 Bandung: Alfabeta.

Widagdo. 1993. Desain, Teori, dan Praktek. Seni Jurnal Pengetahuan dan Penciptaan Seni. BP ISI Yogyakarta III/03. 
